\title{
CFD modelling of multiphase flow distribution in trickle beds
}

\author{
Rodrigo J.G. Lopes, Rosa M. Quinta-Ferreira* \\ GERSE - Group on Environmental, Reaction and Separation Engineering, Department of Chemical Engineering, University of Coimbra, \\ Rua Sílvio Lima, Polo II - Pinhal de Marrocos, 3030-790 Coimbra, Portugal
}

\section{A R T I C L E I N F O}

\section{Article history:}

Received 26 August 2008

Received in revised form

23 November 2008

Accepted 24 November 2008

\section{Keywords:}

CFD

Trickle-bed reactor

Liquid distribution

Liquid holdup

Pressure drop

\begin{abstract}
A B S T R A C T
Multiphase flow in trickle-bed reactors (TBR) is known to be extremely complex and depends on a multitude of effects including the physico-chemical properties of both gas, liquid and solid phases, the ratio of column diameter to particle diameter and most importantly the gas and liquid superficial velocities. Despite several works devoted to the experimental investigation of liquid distribution, there is yet no universal agreement on the influence of interstitial phenomena on overall TBR hydrodynamics.

Consequently, a Eulerian multiphase model was developed to predict the liquid holdup and pressure drop in the trickling flow regime with a 3D computational grid. The multiphase model was optimized in terms of mesh density and time step for the successful hydrodynamic validation activities. The model predictions correctly handled the effect of different numerical solution parameters. Afterwards, particular attention is paid to the consequences on flow development and hydrodynamic parameters of imposing liquid maldistribution at the bed top with three types of liquid distributors. Several computational runs were carried out querying the effect of gas and liquid flow rate on overall hydrodynamics. Computational fluid dynamics (CFD) predictions demonstrated that liquid flow rate had a prominent effect on radial pressure drop profiles at the higher values whereas the gas flow rates had it major outcome at lower regimes. Regarding the liquid holdup predictions, several time averaged for radial and axial profiles illustrated that a five times increase on liquid flow rate cannot be matched by an equivalent change on gas flow rate. The increase in both flow rates was found to smooth the oscillatory behaviour of local phenomena, but the gas flow rate had an outstanding consequence on both hydrodynamic parameters. Finally, CFD simulations at atmospheric conditions were compared with the pressurized ones. Liquid holdup fluctuations of about $25 \%$ between the liquid-rich and the gas-rich zone can be smoothened as long as the operating pressure is increased until 30 bar.
\end{abstract}

(c) 2008 Elsevier B.V. All rights reserved.

\section{Introduction}

A trickle-bed reactor (TBR) is a packed bed in which gas and liquid flow co-currently downwards. Several aspects of hydrodynamics including flow patterns, pressure drop, gas and liquid holdup, wetting efficiency, heat and mass transfer, etc. were extensively studied and reviewed by Satterfield and co-workers [1-6]. TBRs have been commonly used in the petroleum industry for many years and are now gaining widespread use in several other fields from bio and electrochemical industries to the remediation of surface and underground water resources, being also recognized for its applications in advanced wastewaters treatments [7].

For a concurrent downflow trickle-bed reactor, four different flow patterns exist: the gas-continuous or trickle flow at low liquid and gas rates, pulse flow at intermediate liquid and gas rates,

\footnotetext{
* Corresponding author. Tel.: +351 239798723; fax: +351 239798703.

E-mail addresses: rodrigo@eq.uc.pt (R.J.G. Lopes), rosaqf@eq.uc.pt (R.M. Quinta-Ferreira).
}

liquid continuous or dispersed bubble flow at higher liquid rates. The main characteristic in trickling flow is that at a sufficiently low liquid flow, the catalyst particles will only be partially wetted (partial wetting regime). If the liquid flow rate is increased, the partial wetting regime will gradually change to a complete wetting regime [8]. According to this flow map regime, the TBR selection choice is mainly motivated by hydrodynamic considerations in where one or more liquid-solid catalytic reactions occur. Liquid phase maldistribution is then an important factor in the design and scale-up of trickle-bed reactors so that one of the major challenges in its operation is the prevention of liquid flow maldistribution which causes portions of the bed to be incompletely wetted by the flowing liquid. Hence, the catalyst bed is underutilized and reactor performance and productivity is reduced, particularly for liquid limited reactions at low liquid mass velocities.

The research on liquid flow maldistribution is often dedicated in the experimental liquid distribution studies carried out in laboratory scale units using a collector at the outlet of the bed. Recently, several groups had emphasized the use of tomographic and video imaging techniques, which provides the flow distribution infor- 


\begin{tabular}{|c|c|}
\hline \multicolumn{2}{|c|}{ Nomenclature } \\
\hline$C_{1 \varepsilon}, C_{2 \varepsilon}$ & $k-\varepsilon$ model parameters: $1.44,1.92$ \\
\hline$E_{1}, E_{2}$ & Ergun's constants \\
\hline$\vec{F}_{i}$ & interphase momentum exchange term of $i$ th phase \\
\hline$\vec{g}$ & gravitational acceleration, $9.81 \mathrm{~s}^{2}$ \\
\hline G & gas mass flux $\left(\mathrm{kg} / \mathrm{m}^{2} \mathrm{~s}\right)$ \\
\hline$k$ & $k-\varepsilon$ model kinetic energy \\
\hline$L$ & liquid mass flux ( $\left.\mathrm{kg} / \mathrm{m}^{2} \mathrm{~s}\right)$ \\
\hline$p$ & pressure (bar) \\
\hline$\Delta p$ & total pressure drop $(\mathrm{Pa})$ \\
\hline $\operatorname{Re}_{i}$ & $\begin{array}{l}\text { Reynolds number of } i \text { th phase }\left[\rho_{i} u_{i} d_{\mathrm{p}} / \mu_{i}\right] \text { (dimen- } \\
\text { sionless) }\end{array}$ \\
\hline$\vec{u}$ & superficial vector velocity (m/s) \\
\hline \multicolumn{2}{|c|}{ Greek letters } \\
\hline$\alpha_{i}$ & volume fraction of $i$ th phase \\
\hline$\varepsilon$ & $k-\varepsilon$ model dissipation energy \\
\hline$\varepsilon_{L}$ & liquid holdup \\
\hline$\varepsilon_{G}$ & gas holdup \\
\hline$\varepsilon_{S}$ & solid volume fraction \\
\hline$\mu_{i}$ & viscosity of $i$ th phase (Pas) \\
\hline$\rho_{i}$ & density of $i$ th phase $\left(\mathrm{kg} / \mathrm{m}^{3}\right)$ \\
\hline$\sigma_{k}, \sigma_{\varepsilon}$ & $k-\varepsilon$ model parameters: $1.2,1.0$ \\
\hline$\hat{\tau}_{i}$ & shear stress tensor of $i$ th phase $(\mathrm{Pa})$ \\
\hline \multicolumn{2}{|c|}{ Subscripts } \\
\hline G & gas phase \\
\hline$i$ & ith phase \\
\hline$L$ & liquid phase \\
\hline$S$ & solid phase \\
\hline
\end{tabular}

mation more quantitatively [9-12]. The flow pattern and liquid maldistribution have been found to be dependent not only on the physico-chemical properties of the liquid (density, viscosity, surface tension), liquid and gas flow rates $[13,14]$ but also on the ratio of reactor diameter to catalyst particle diameter [3,14,15], wettability [16], and shape and orientation of catalyst particles [8,17]. And ineffective liquid inlet distributor may also lead to poor liquid distribution due to large non-wetted regions of the packed bed.

Consequently, the assumption of uniform wetting efficiency throughout the reactor made in conventional reactor models is found to overpredict the reaction rate [18]. The solution to this problem requires a deep understanding of interstitial flow in trickle beds. A number of models of the liquid distribution have been developed in the past two decades based on different concepts or governing principles [19-24]. Sáez and Carbonell developed a model based on concept of relative permeability [25] whereas slit models proposed by Holub et al. and Iliuta et al. are based on phenomenological principles $[26,27]$. In this model the local flow of liquid and gas around the particles is modelled by assuming flow in rectangular inclined slits of width related to void fraction of the medium. The interfacial force model presented by Attou and Ferschneider takes into account the drag force on each phase with the contribution from the particle-fluid interaction as well as from the fluid-fluid interaction [28]. Recently, and with the increasing computational power and development of efficient computational fluid dynamics (CFD) algorithms multiphase flow in TBR has been modelled in a fashionable manner accounting for a new methodology for liquid flow distribution studies by means of numerical simulations. In this category, Souadnia and Latifi and Atta et al. have used the porous media model $[29,30]$ and Jiang et al. and Gunjal et al. investigated the TBR hydrodynamics through the $k$-fluid model [31,32].

In the present work, the Eulerian framework is applied here to describe the multiphase flow in a three-dimensional geometry which allows the capture of interstitial flow in the packed bed. The Euler model is based on a set of continuity and momentum equations of each fluid phase with appropriate closures for the interaction forces. The individual drag forces are related with the flow velocities and volume fractions of each phase and to the physical properties of the gas, liquid and solid phases obtained from the fluid-fluid interfacial force model [28]. First, several computational runs were performed for the purpose of hydrodynamic model validation either in terms of liquid holdup or two-phase pressure drop. Afterwards, the quantitative understanding of flow maldistribution at the catalyst scale in the trickle bed is accomplished through the evaluation of time averaged axial and radial profiles for both hydrodynamic parameters. The influences of liquid distributor geometry as well as the effect of gas and liquid flow rates are investigated in the trickling flow regime.

\section{CFD modelling}

\subsection{Euler-Euler momentum equation}

Multiphase flow in the trickle-bed reactor was modelled using a multifluid CFD Euler-Euler two-fluid model implemented in commercial software FLUENT 6. In the Eulerian two-fluid approach, the gas and liquid phases are treated mathematically as interpenetrating continua. The derivation of the conservation equations for mass, momentum and energy for each of the individual phases is done by ensemble averaging the local instantaneous balances for each of the phases. At the subgrid scale, the two-fluid phases are described by the corresponding volume fractions and the pressure constrains the velocity field to ensure that the sum of the phase volume fractions equals unity. Fluids, gas and liquid, are treated as incompressible, and a single pressure field is shared by all phases.

FLUENT uses phase-weighted averaging for turbulent multiphase flow, and then no additional turbulent dispersion term is introduced into the continuity equation. The mass conservation equation for each phase is written in Eq. (1).

$\frac{\partial}{\partial t}\left(\rho_{i} \alpha_{i}\right)+\nabla \cdot\left(\alpha_{i} \rho_{i} \vec{u}_{i}\right)=0$

where $\rho_{i}, \alpha_{i}$ and $\vec{u}_{i}$ represent the density, volume fraction and mean velocity, respectively, of phase $i(L$ or $G$ ). As referred, the liquid phase $L$ and the gas phase $G$ are assumed to share space in proportion to their volume such that their volume fractions sums to unity in the cells domain:

$\alpha_{L}+\alpha_{G}=1$

The momentum conservation equation for the phase $i$ after averaging is written in Eq. (3).

$$
\begin{aligned}
\frac{\partial}{\partial t}\left(\rho_{i} \alpha_{i} \vec{u}_{i}\right)+ & \nabla \cdot\left(\rho_{i} \alpha_{i} \vec{u}_{i} \vec{u}_{i}\right)=-\alpha_{i} \nabla p+\nabla \cdot \overline{\bar{\tau}}_{e f f}+\rho_{i} \alpha_{i} \vec{g} \\
& +\sum_{p=1}^{n} \vec{F}_{i j}\left(\vec{U}_{i j}-\vec{U}_{j i}\right)
\end{aligned}
$$

$p$ is a pressure shared by the two phases and $\vec{F}_{j i}$ represents the interphase momentum exchange terms. The Reynolds stress tensor $\overline{\bar{\tau}}_{\text {eff }}$ is related to the mean velocity gradients using a Boussinesq hypothesis as expressed in Eq. (4).

$$
\begin{aligned}
\overline{\bar{\tau}}_{e f f}= & \alpha_{i}\left(\mu_{\text {lam }, i}+\mu_{t, i}\right)\left(\nabla \vec{u}_{i}+\nabla \vec{u}_{i}^{T}\right) \\
& -\frac{2}{3} \alpha_{i}\left(\rho_{i} k_{i}+\left(\mu_{\text {lam }, i}+\mu_{t, i}\right) \nabla \cdot \vec{u}_{i}\right) \overline{\bar{I}}
\end{aligned}
$$




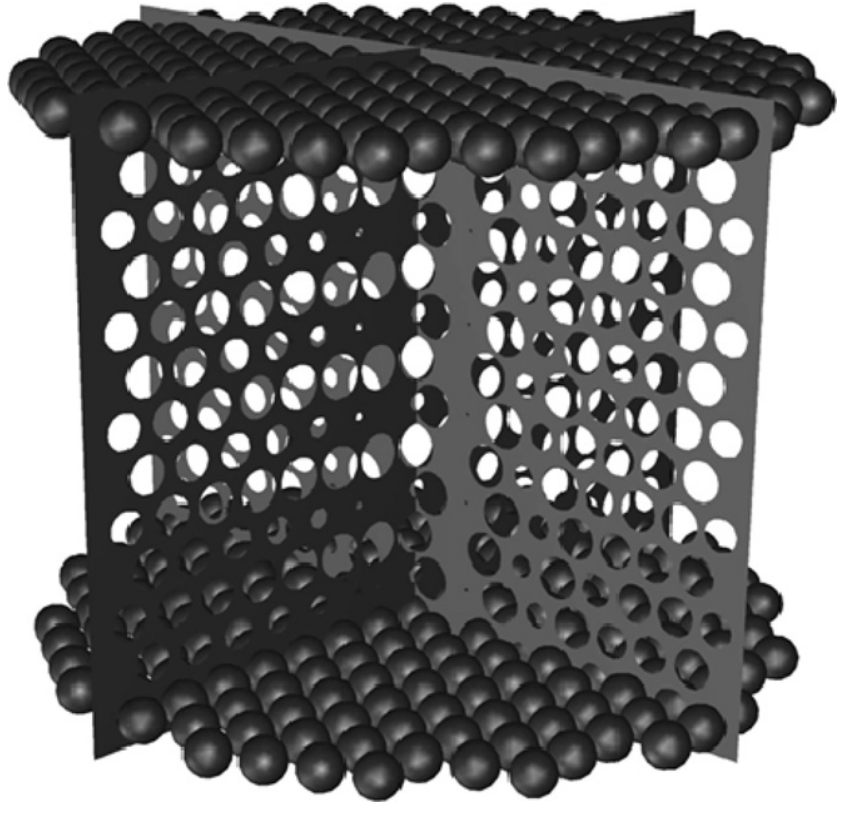

Fig. 1. Representative axial planes and catalytic packing geometry for the trickle-bed reactor.

\section{Table 1}

Numerical solution parameters used in the CFD simulation.

\begin{tabular}{ll}
\hline Grid & $1000 \mathrm{~mm}$ (axial) $\times 50 \mathrm{~mm}$ (radial) \\
Cell size & $0.01-0.20 \mathrm{~mm}$ (tetrahedral cells) \\
Particle diameter & $2 \mathrm{~mm}(\mathrm{spheres})$ \\
Time step & $10^{-5}$ to $10^{-2} \mathrm{~s}$ \\
Convergence criteria & $10^{-5}$ to $10^{-2}$ \\
Discretization & \\
$\quad$ Momentum & MUSCL \\
Volume fraction & QUICK \\
Turbulent kinetic energy & QUICK \\
Turbulent dissipation rate & QUICK \\
Iterations & $\approx 10-50,000$ \\
Under-relaxation parameters & Pressure: 0.3 \\
& Density: 1 \\
& Body forces: 1 \\
& Momentum: 0.7 \\
& Volume fraction: 1 \\
& Turbulent kinetic energy: 0.8 \\
& Turbulent dissipation rate: 0.8 \\
Turbulence model & Turbulent viscosity: 1 \\
\hline & Attou and Ferschneider [28] \\
& Dispersed phase standard $k-\varepsilon$ \\
\hline &
\end{tabular}

\subsection{Drag force formulation}

The most important interphase force is the drag force resulting from the mean relative velocity between the two phases and an additional contribution resulting from turbulent fluctuations in
Table 2

Relevant thermophysical properties of gas and liquid phases.

\begin{tabular}{lcl}
\hline Properties & Value $\left(T=25^{\circ} \mathrm{C}\right)$ & Units \\
\hline $\begin{array}{l}\text { Gas phase } \\
\text { Density }\end{array}$ & $\begin{array}{c}35.67(30 \mathrm{bar}) \\
\text { Viscosity }\end{array}$ & $\mathrm{kg} / \mathrm{m}^{3}$ \\
Liquid phase & $1.845 \times 10^{-5}(1$ bar $)$ & $\mathrm{Pas}$ \\
$\begin{array}{l}\text { Viscosity } \\
\text { Density }\end{array}$ & $8.925 \times 10^{-4}$ & $\mathrm{Pas}$ \\
Surface tension & 998.4 & $\mathrm{~kg} / \mathrm{m}^{3}$ \\
\hline
\end{tabular}

the volume fraction due to averaging of momentum equations [33] Interphase coupling terms, $\vec{F}_{i j}$, were formulated based on similar equations to those that are typically used to express the pressure drop for packed beds by means of Ergun equation. We have used the model of Attou and Ferschneider, which includes gas-liquid interaction forces and it was developed for the regime in which liquid flows in the form of film [28]. The interphase coupling terms are written in terms of interstitial velocities and phase volume fractions for gas-liquid, gas-solid and liquid-solid momentum exchange forms as expressed in Eqs. (5)-(7):

$$
\begin{aligned}
F_{G L}= & \varepsilon_{G}\left(\frac{E_{1} \mu_{G}\left(1-\varepsilon_{G}\right)^{2}}{\varepsilon_{G}^{2} d_{\mathrm{p}}^{2}}\left[\frac{\varepsilon_{S}}{1-\varepsilon_{G}}\right]^{2 / 3}\right. \\
& \left.+\frac{E_{2} \rho_{G}\left(u_{G}-u_{L}\right)\left(1-\varepsilon_{G}\right)}{\varepsilon_{G} d_{\mathrm{p}}}\left[\frac{\varepsilon_{S}}{1-\varepsilon_{G}}\right]^{1 / 3}\right) \\
F_{G S}= & \varepsilon_{G}\left(\frac{E_{1} \mu_{G}\left(1-\varepsilon_{G}\right)^{2}}{\varepsilon_{G}^{2} d_{\mathrm{p}}^{2}}\left[\frac{\varepsilon_{S}}{1-\varepsilon_{G}}\right]^{2 / 3}\right. \\
& \left.+\frac{E_{2} \rho_{G} u_{G}\left(1-\varepsilon_{G}\right)}{\varepsilon_{G} d_{\mathrm{p}}}\left[\frac{\varepsilon_{S}}{1-\varepsilon_{G}}\right]^{1 / 3}\right) \\
F_{L S}= & \varepsilon_{L}\left(\frac{E_{1} \mu_{L} \varepsilon_{S}^{2}}{\varepsilon_{L}^{2} d_{\mathrm{p}}^{2}}+\frac{E_{2} \rho_{L} u_{G} \varepsilon_{S}}{\varepsilon_{L} d_{\mathrm{p}}}\right)
\end{aligned}
$$

\subsection{Turbulence modelling}

Multiphase flows in trickle-beds are often characterized by low interaction regimes so that the flow is often assumed laminar either at the reactor level or at the catalyst particle scale. Nevertheless, several studies have come across at the transition to turbulence, the level of turbulence intensity in the void space, and the description of flow regimes in fixed bed flow. Laser anemometry and flow visualization studies were carried out by Dybbs et al. on the investigation of liquid flow regimes in hexagonal packings of spheres and rods [34]. The authors concluded that there are four flow regimes for different ranges of Reynolds number, based on interstitial or pore velocity $R e_{i}=R e / \varepsilon$ : for $R e_{i}<1$, the creeping flow is dominated by viscous forces and pressure drop is linearly proportional to inter-

\begin{tabular}{|c|c|c|c|c|c|c|}
\hline$G\left(\mathrm{~kg} / \mathrm{m}^{2} \mathrm{~s}\right)$ & $L\left(\mathrm{~kg} / \mathrm{m}^{2} \mathrm{~s}\right)$ & $P$ (bar) & $k_{G}\left(\mathrm{~mm}^{2} / \mathrm{s}^{2}\right)$ & $k_{L}\left(\mathrm{~mm}^{2} / \mathrm{s}^{2}\right)$ & $\varepsilon_{G}\left(\mathrm{~mm}^{2} / \mathrm{s}^{3}\right)$ & $\varepsilon_{L}\left(\mathrm{~mm}^{2} / \mathrm{s}^{3}\right)$ \\
\hline 0.3 & 2 & 1 & $1.310 \times 10^{3}$ & $1.329 \times 10^{-1}$ & $4.895 \times 10^{3}$ & $8.640 \times 10^{-4}$ \\
\hline 0.3 & 10 & 1 & $1.310 \times 10^{3}$ & 2.222 & $4.895 \times 10^{3}$ & 0.2415 \\
\hline 0.1 & 5 & 1 & $1.915 \times 10^{2}$ & 0.6607 & $1.047 \times 10^{2}$ & $2.135 \times 10^{-2}$ \\
\hline 0.7 & 5 & 1 & $5.770 \times 10^{3}$ & 0.6607 & $9.498 \times 10^{4}$ & $2.135 \times 10^{-2}$ \\
\hline 0.3 & 2 & 30 & 1.408 & 0.1329 & 0.1726 & $8.640 \times 10^{-4}$ \\
\hline 0.3 & 10 & 30 & 1.408 & 2.222 & 0.1726 & 0.2415 \\
\hline 0.1 & 5 & 30 & 0.2059 & 0.6607 & $3.690 \times 10^{-3}$ & $2.135 \times 10^{-2}$ \\
\hline 0.7 & 5 & 30 & 6.204 & 0.6607 & 3.349 & $2.135 \times 10^{-2}$ \\
\hline
\end{tabular}
stitial velocity; for $1 \leq R e_{i} \leq 150$, the steady laminar inertial flow in which pressure drop depends nonlinearly on interstitial veloc-

Table 3

Inlet boundary conditions for the gas and liquid phases: turbulent kinetic energy $\left(k_{i}\right)$ and turbulent dissipation rate $\left(\varepsilon_{i}\right)$ at $T=25^{\circ} \mathrm{C}$. 


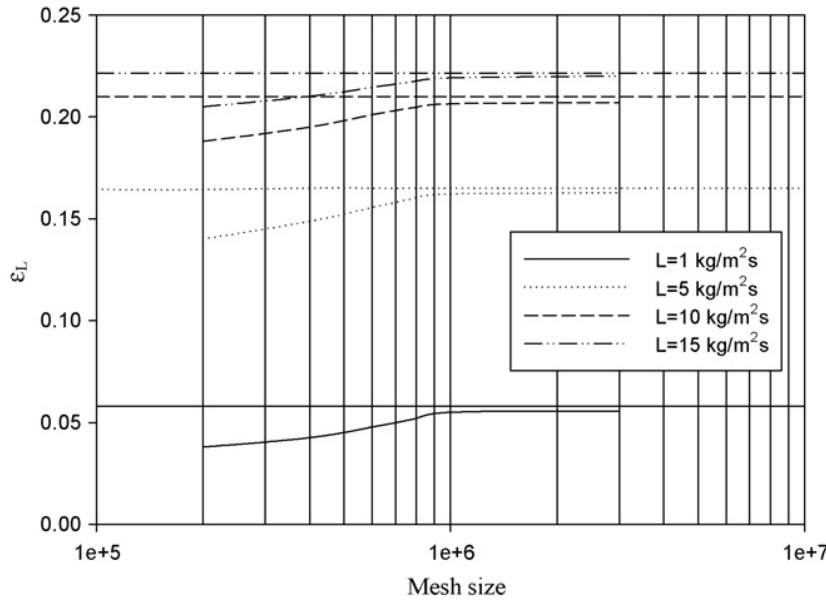

Fig. 2. Comparison of liquid holdup predictions at different liquid flow rates for different mesh resolutions $\left(G=0.1 \mathrm{~kg} / \mathrm{m}^{2} \mathrm{~s}, P=30 \mathrm{bar}, d_{\mathrm{p}}=2 \mathrm{~mm}\right.$ and experimental data from Nemec and Levec [42]).

ity; for $150 \leq R e_{i} \leq 300$, the laminar inertial flow is unsteady; and for $R e_{i}>300$, the flow is highly unsteady, chaotic and qualitatively resembling turbulent flow. Similarly, Gunjal et al. used a laminar model up to $R e_{i}=204$ and turbulent models for $R e_{i}=1000-2000$ [35].

Consequently, since the Reynolds numbers range for the gas phase is wide (min: 10, max: 2500), $k-\varepsilon$ dispersed model was applied for turbulence modelling. For incompressible flows, the turbulence parameters are calculated from Eqs. (8) and (9):

$$
\begin{aligned}
\frac{\partial}{\partial t}\left(\rho_{L} \alpha_{L} k_{L}\right) & +\nabla \cdot\left(\rho_{L} \alpha_{L} \vec{u}_{L} k_{L}\right)=\nabla \cdot\left(\alpha_{L} \frac{\mu_{t, L}}{\sigma_{k}} \nabla k_{L}\right) \\
& +\alpha_{L} G_{k, L}-\alpha_{L} \rho_{L} \varepsilon_{L}+\alpha_{L} \rho_{L} \prod_{k L}
\end{aligned}
$$

$$
\begin{aligned}
\frac{\partial}{\partial t}\left(\rho_{L} \alpha_{L} \varepsilon_{L}\right) & +\nabla \cdot\left(\rho_{L} \alpha_{L} \vec{u}_{L} \varepsilon_{L}\right)=\nabla \cdot\left(\alpha_{L} \frac{\mu_{t, L}}{\sigma_{\varepsilon}} \nabla \varepsilon_{L}\right) \\
& +\alpha_{L} \frac{\varepsilon_{L}}{k_{L}} \times\left(C_{1 \varepsilon} G_{k, L}-C_{2 \varepsilon} \rho_{L} \varepsilon_{L}\right)+\alpha_{L} \rho_{L} \prod_{\varepsilon L}
\end{aligned}
$$

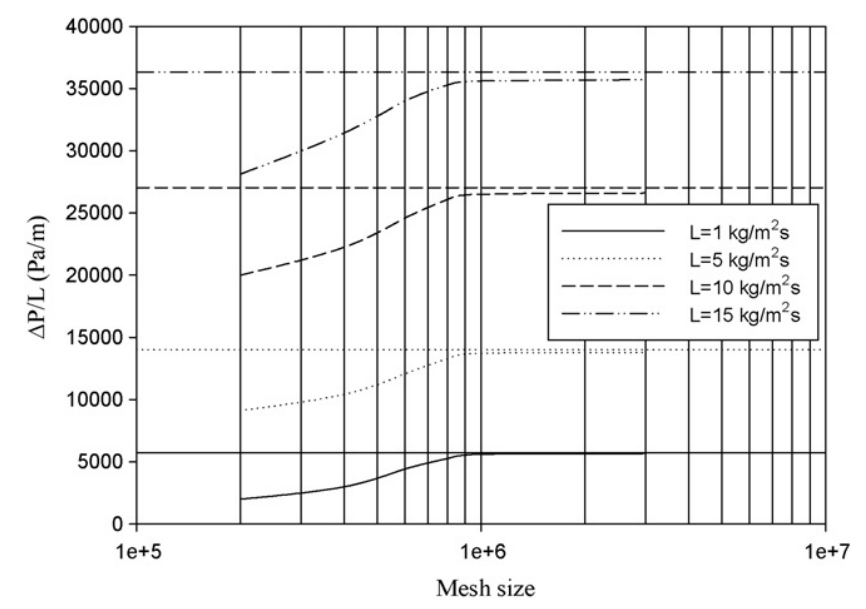

Fig. 3. Comparison of two-phase pressure drop predictions at different liquid flow rates for different mesh resolutions $\left(G=0.5 \mathrm{~kg} / \mathrm{m}^{2} \mathrm{~s}, P=30 \mathrm{bar}, d_{\mathrm{p}}=2 \mathrm{~mm}\right.$ and experimental data from Nemec and Levec [42]).

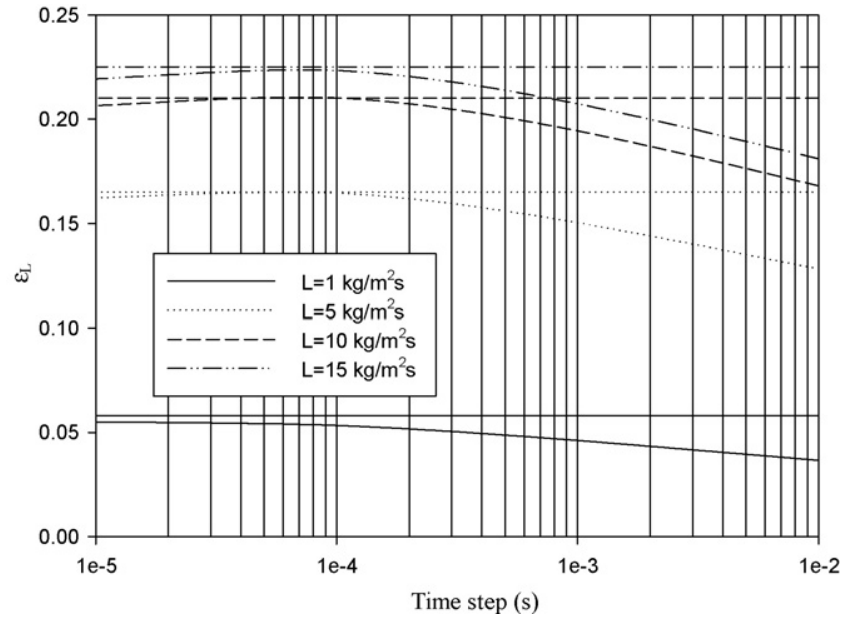

Fig. 4. Effect of time step on liquid holdup predictions at different liquid flow rates ( $10^{6}$ of tetrahedral cells, $G=0.1 \mathrm{~kg} / \mathrm{m}^{2} \mathrm{~s}, P=30 \mathrm{bar}, d_{\mathrm{p}}=2 \mathrm{~mm}$ and experimental data from Nemec and Levec [42]).

$G_{k}$ is the generation of turbulent kinetic energy, $k$, due to the mean velocity gradients (turbulent stress) as expressed in Eq. (10).

$G_{k}=-\rho \overline{U_{i}^{\prime} U_{j}^{\prime}} \frac{\partial U_{j}}{\partial x_{i}}$

$C_{1 \varepsilon}$ and $C_{2 \varepsilon}$ are the constants of standard $k-\varepsilon$ model whereas $\sigma_{k}$ and $\sigma_{\varepsilon}$ are the turbulent Prandtl numbers for $k$ and $\varepsilon$, respectively.

\section{Numerical simulation}

\subsection{Computational grid}

Trickle-bed reactor was designed using regular shape catalyst particles for multifluid Eulerian simulations [36]. Gas-liquid flows through a catalytic bed comprised of monosized, spherical, solid particles arranged in a cylindrical container of a pilot TBR unit (50 mm internal diameter $\times 1.0 \mathrm{~m}$ length). The computational mesh of the catalytic bed was shortened in length given the high memory requirements so that the reactor was filled with 13 layers in which around 200 non-overlapping spherical particles of $2 \mathrm{~mm}$ diameter were necessary for each axial layer. The first and the last catalyst layers as well as two representative axial planes are shown in Fig. 1. In order to avoid numerical difficulties associated with the mesh generation also reported in the literature [37], the catalyst particles

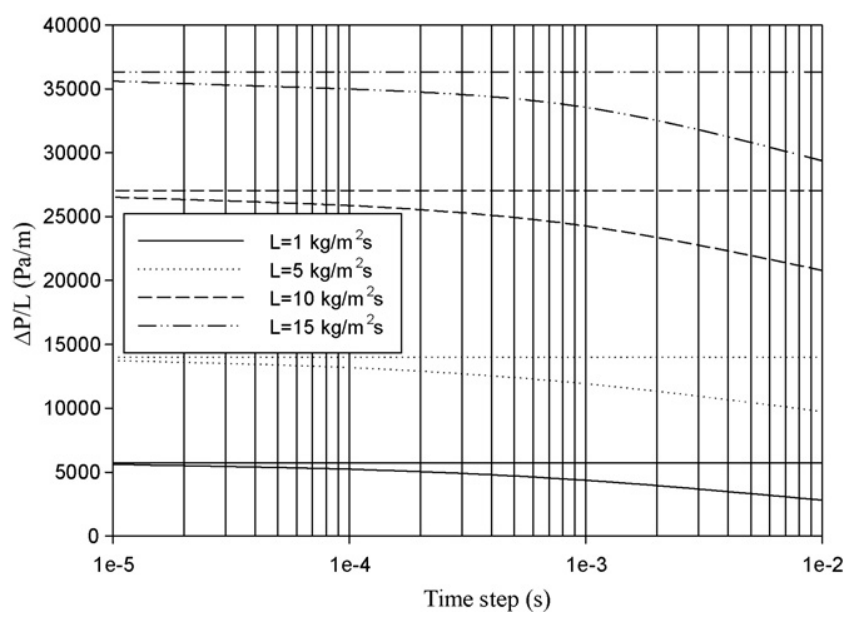

Fig. 5. Effect of time step on two-phase pressure drop predictions at different liquid flow rates $\left(10^{6}\right.$ of tetrahedral cells, $G=0.5 \mathrm{~kg} / \mathrm{m}^{2} \mathrm{~s}, P=30 \mathrm{bar}, d_{\mathrm{p}}=2 \mathrm{~mm}$ and experimental data from Nemec and Levec [42]). 

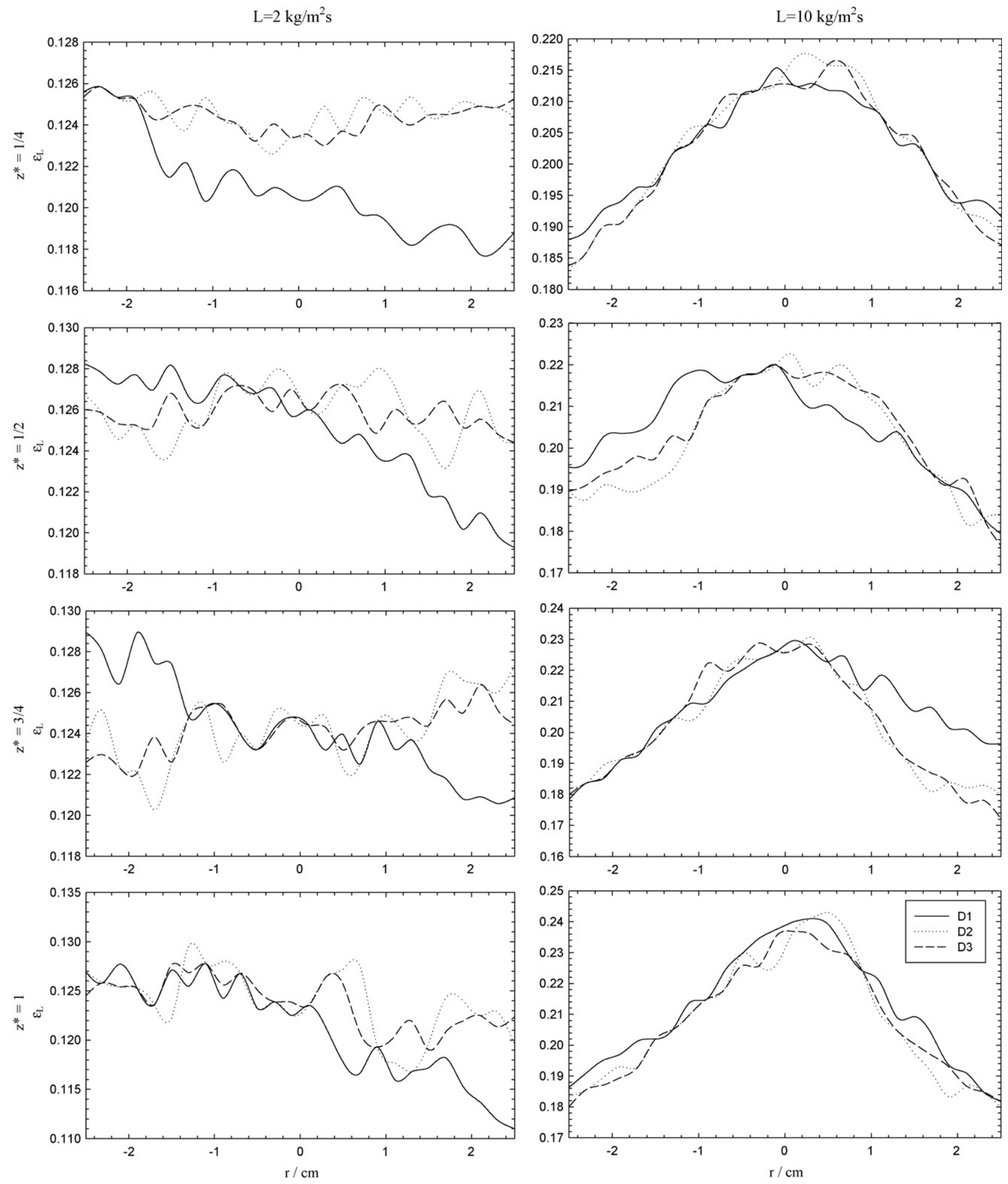

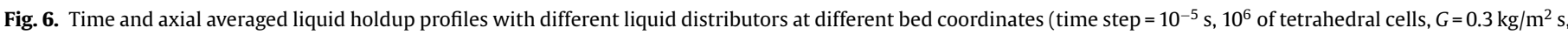
$P=30$ bar, $d_{\mathrm{p}}=2 \mathrm{~mm}$ ).

do not touch each other and the distance gap was fixed by $2-3 \%$ of the sphere diameter as described elsewhere [38].

The grid of catalytic bed was created using the integrated solid modelling and meshing commercial program GAMBIT [39]. Different mesh densities and discretization parameters were applied in the evaluation of probable geometrical errors arising from the mesh aperture. Consecutively, the number of cells necessary to produce grid independent results for the hydrodynamic parameters was increased from $2 \times 10^{5}$ to $3 \times 10^{6}$, with other numerical solution parameters including operating conditions given by Table 1 while Table 2 summarizes the gas and liquid thermophysical properties used in the Eulerian CFD simulations.

\subsection{Operating and boundary conditions}

High-pressure operation was simulated at 30 bar total operating pressure with inflow gas $\left(G=0.1-0.7 \mathrm{~kg} / \mathrm{m}^{2} \mathrm{~s}\right)$ and liquid $\left(L=1-15 \mathrm{~kg} / \mathrm{m}^{2} \mathrm{~s}\right)$ being distributed through one of three designed 


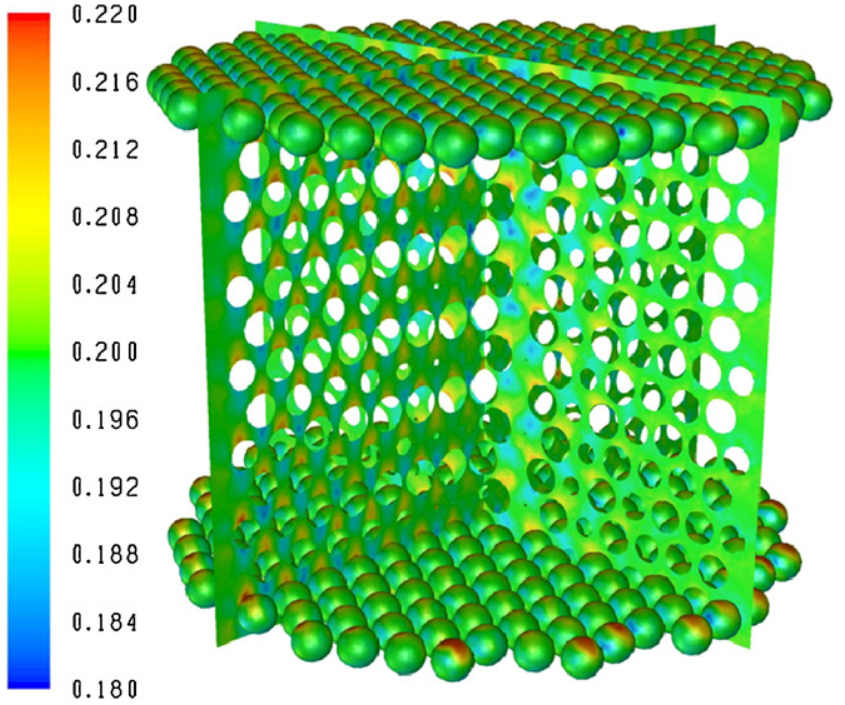

Fig. 7. Instantaneous snapshot of liquid holdup taken at two axial planes (Fig. 1) and two catalyst layers (time step $=10^{-5} \mathrm{~s}, 10^{6}$ of tetrahedral cells, $L=2 \mathrm{~kg} / \mathrm{m}^{2} \mathrm{~s}$, $G=0.3 \mathrm{~kg} / \mathrm{m}^{2} \mathrm{~s}, P=30$ bar, $d_{\mathrm{p}}=2 \mathrm{~mm}$, D2 distributor).

distributors: D1 corresponds to a single-point entry distributor with an $0.2 \mathrm{~mm}$ inlet diameter, D2 corresponds to a 60-hole distributor and D3 replicates a uniform distributor at the top of trickle-bed reactor. The boundary conditions were specified based on FLUENT documentation [33]. Inlet turbulent kinetic energy $(k)$ was estimated from turbulence intensity as expressed in Eq. (11).

$k=\frac{3}{2}(u I)^{2}$

where $I$ is the turbulence intensity being given by Eq. (12).

$I=0.16\left(\operatorname{Re}_{d_{H}}\right)^{-1 / 8}$

Inlet turbulent dissipation rate $(\varepsilon)$ was estimated from the turbulent viscosity ratio as expressed by Eq. (13).

$\varepsilon=\rho C_{\mu} \frac{k^{2}}{\mu}\left(\frac{\mu_{t}}{\mu}\right)^{-1}$

where $C_{\mu}$ is an empirical constant specified in the turbulence model (0.09). At $25^{\circ} \mathrm{C}$ and two different operating pressures 1 and 30 bar, the inlet turbulent kinetic energy and inlet turbulent dissipation rate for the gas and liquid phases are given in Table 3. Computations are time dependent and were carried out until steady state conditions were reached. During the simulations of turbulent multiphase flow, it was employed standard wall functions available in

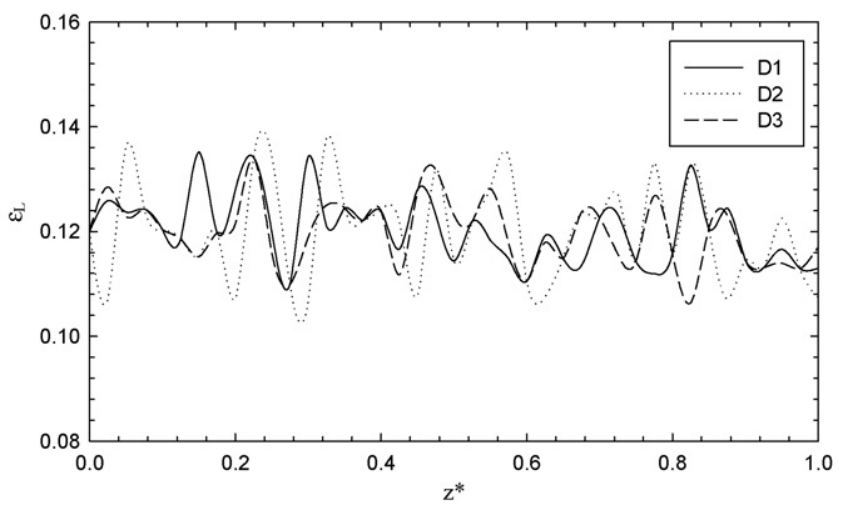

Fig. 8. Time and radial averaged liquid holdup profiles at $L=2 \mathrm{~kg} / \mathrm{m}^{2} \mathrm{~s}$ with different liquid distributors (time step $=10^{-5} \mathrm{~s}, 10^{6}$ of tetrahedral cells, $G=0.3 \mathrm{~kg} / \mathrm{m}^{2} \mathrm{~s}$, $P=30$ bar, $d_{\mathrm{p}}=2 \mathrm{~mm}$ ). the commercial CFD solver. The calculations have been carried out on a Linux cluster based on AMD64 Dual-Core $2.2 \mathrm{GHz}$ processor workstation.

\subsection{Numerical solution method}

In the CFD multiphase simulations, the phase coupled SIMPLE [40] algorithm was used for the pressure-velocity coupling which is an extension of the SIMPLE algorithm [41] to multiphase flows. The velocities are solved coupled by phases in a segregated fashion. The block algebraic multigrid scheme used by the density-based solver is used to solve a vector equation formed by the velocity components of all phases simultaneously. Afterwards, a pressure correction equation is built based on total volume continuity rather than mass continuity. Pressure and velocities are then corrected so as to satisfy the continuity constraint. For incompressible multiphase flow, the pressure-correction equation takes the form of Eq. (14).

$$
\begin{gathered}
\sum_{k=1}^{n} \frac{1}{\rho_{r k}}\left\{\frac{\partial}{\partial t} \alpha_{k} \rho_{k}+\nabla \cdot \alpha_{k} \rho_{k} \vec{v}_{k}^{\prime}+\nabla \cdot \alpha_{k} \rho_{k} \vec{v}_{k}^{*}\right. \\
\left.-\left(\sum_{l=1}^{n}\left(\dot{m}_{l k}-\dot{m}_{k l}\right)\right)\right\}=0
\end{gathered}
$$

where $\rho_{r k}$ is the phase reference density for the $k$ th phase (defined as the total volume average density of phase $k$ ), $\vec{v}_{k}^{\prime}$ is the velocity correction for the $k$ th phase, and $\vec{v}_{k}^{*}$ is the value of $\vec{v}_{k}$ at the current iteration. The velocity corrections are themselves expressed as functions of the pressure corrections. The volume fractions are obtained from the phase continuity equations. In discretized form, the $k$ th volume fraction is given by Eq. (15).

$a_{p, k} \alpha_{k}=\sum_{n b}\left(a_{n b, k} \alpha_{n b, k}\right)+b_{k}=R_{k}$

\section{Results and discussion}

\subsection{Hydrodynamic validation: mesh sensitivity and time step}

In this section, the numerical methodology is validated in terms of well-known hydrodynamic parameters by checking the mesh sensitivity and time step and by comparing the numerical results against the experimental data available in the open literature [42]. In order to check the mesh independence, the refinement is performed in seven levels: three levels for the coarser meshes with $2 \times 10^{5}, 4 \times 10^{5}, 6 \times 10^{5}$ of tetrahedral cells and four levels for the

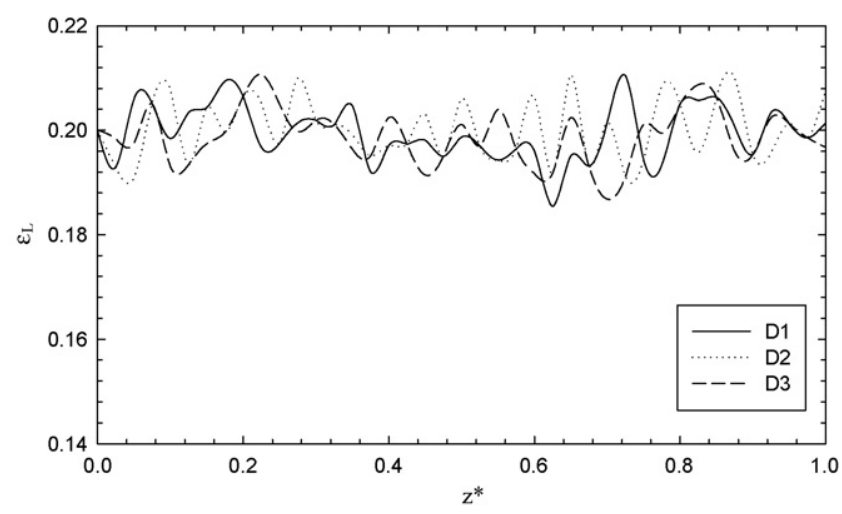

Fig. 9. Time and radial averaged liquid holdup profiles at $L=10 \mathrm{~kg} / \mathrm{m}^{2} \mathrm{~s}$ with different liquid distributors (time step $=10^{-5} \mathrm{~s}, 10^{6}$ of tetrahedral cells, $G=0.3 \mathrm{~kg} / \mathrm{m}^{2} \mathrm{~s}$, $P=30$ bar, $\left.d_{\mathrm{p}}=2 \mathrm{~mm}\right)$. 

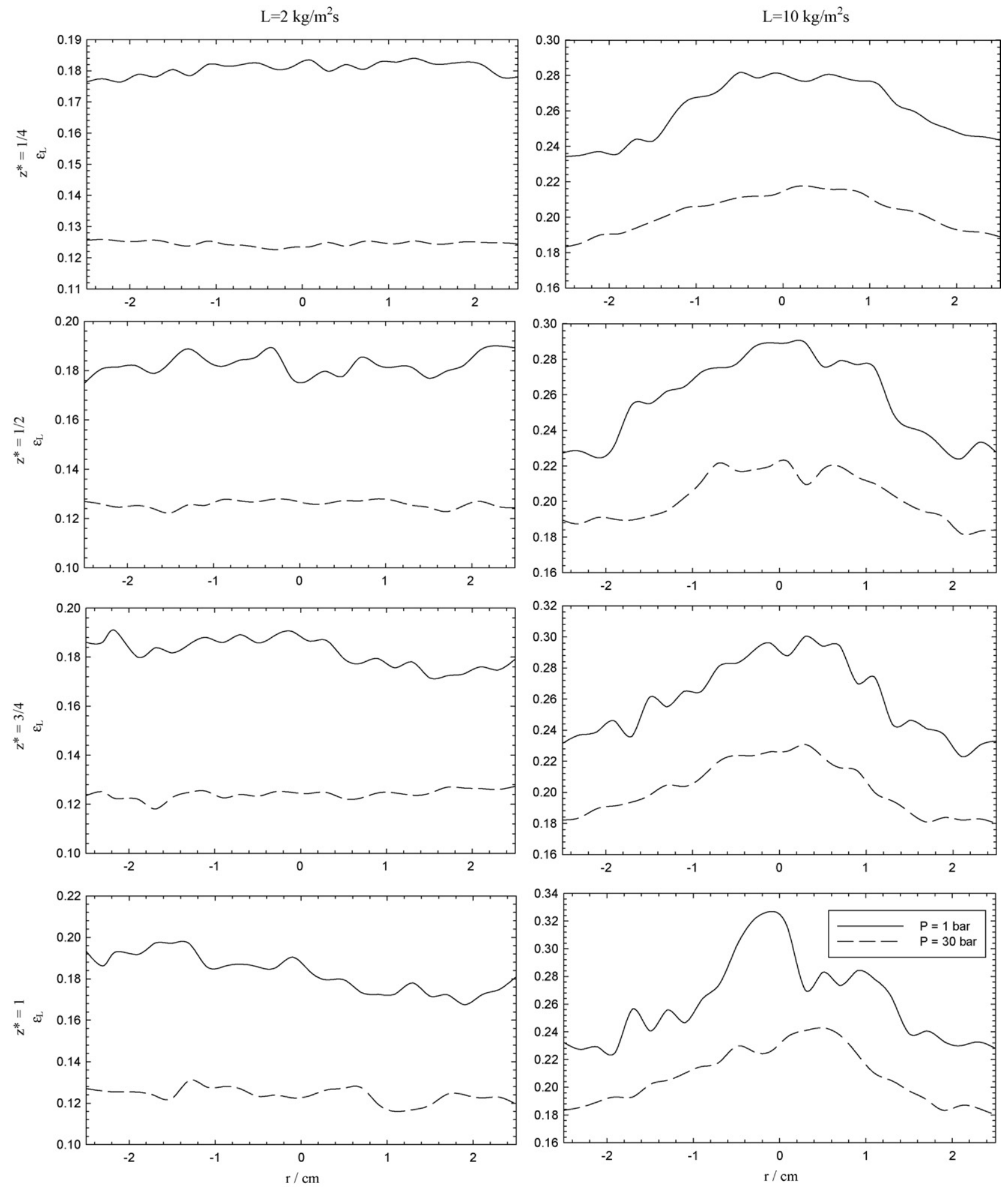

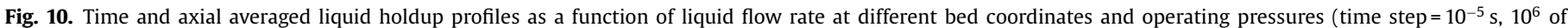
tetrahedral cells, $G=0.3 \mathrm{~kg} / \mathrm{m}^{2} \mathrm{~s}, d_{\mathrm{p}}=2 \mathrm{~mm}$, D2 distributor).

finer meshes with $8 \times 10^{5}$ and $1 \times 10^{5}, 2 \times 10^{5}, 3 \times 10^{5}$ of tetrahedral cells.

Fig. 2 displays the influence of number of tetrahedral cells on the liquid holdup predictions with four simulation sets at constant liquid flow rate: $L=1,5,10$ and $15 \mathrm{~kg} / \mathrm{m}^{2} \mathrm{~s}$ at $G=0.1 \mathrm{~kg} / \mathrm{m}^{2} \mathrm{~s}$ and $P=30$ bar. As it can be seen, the increase of mesh density led to an asymptotic solution as one increase the number of cells of one million onwards. The horizontal lines in the semi-log plot of Fig. 2 correspond to the experimental liquid holdup value [42]. According to Fig. 2, the relative error obtained with $2 \times 10^{5}$ of cells between the CFD liquid holdup predictions and experimental data was 23.8 , $12.4,6.2$ and $4.1 \%$ for $L=1,5,10$ and $15 \mathrm{~kg} / \mathrm{m}^{2} \mathrm{~s}$, respectively. Let the true liquid holdup be the experimental value, $\varepsilon_{\mathrm{L}, \mathrm{EXP}}$, and the computed liquid holdup value, $\varepsilon_{\mathrm{L}, \mathrm{CFD}}$, then the relative error was defined by: relative error $(\%)=\left(\varepsilon_{\mathrm{L}, \mathrm{CFD}}-\varepsilon_{\mathrm{L}, \mathrm{EXP}}\right) / \varepsilon_{\mathrm{L}, \mathrm{EXP}}$. At the same gas flow rate and operating pressure, the relative error shifted to $1.5,1.3$, 


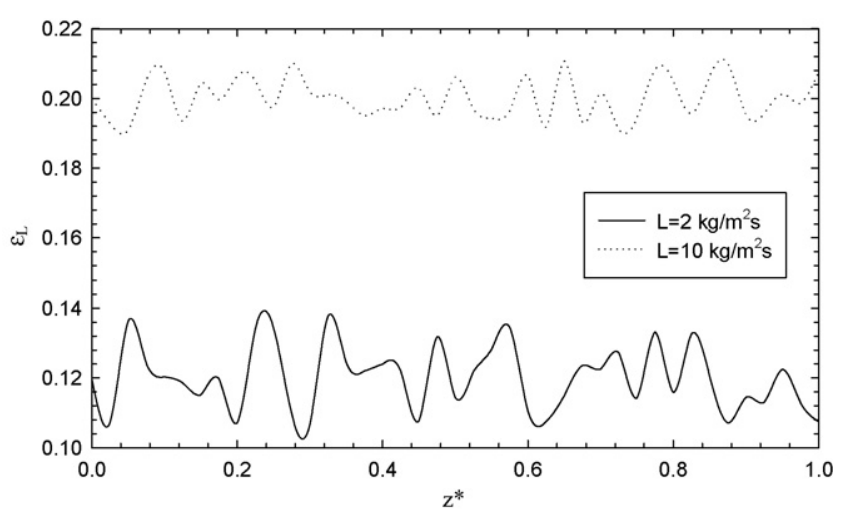

Fig. 11. Time and radial averaged liquid holdup profiles at different liquid flow rates (time step $=10^{-5} \mathrm{~s}, 10^{6}$ of tetrahedral cells, $G=0.3 \mathrm{~kg} / \mathrm{m}^{2} \mathrm{~s}, P=30$ bar, $d_{\mathrm{p}}=2 \mathrm{~mm}$, D2 distributor).

1.2 and $1.0 \%$ for the equivalent liquid flow rates with one million of cells. The CFD calculations performed with a further increase of mesh density with either 2 or $3 \times 10^{6}$ of tetrahedral cells did not show any improvement as the relative error became invariable with a value of $1.0 \%$ for the liquid holdup. In what concerns two-phase pressure drop, Fig. 3 shows a semi-log plot for the frictional pressure drop along the packed bed at $G=0.1 \mathrm{~kg} / \mathrm{m}^{2}$ s and $P=30$ bar with the same set of liquid flow rates. The horizontal lines in the semi$\log$ plot of Fig. 3 correspond to the experimental value of two-phase pressure drop [42]. The CFD calculations performed with the coarsest mesh $\left(2 \times 10^{5}\right.$ of tetrahedral cells) exhibited a relative error of $32.7,24.8,18.3$ and 14.3 while the computed results corresponding to $10^{6}$ of cells gave a relative error of $1.6,1.5,1.2$ and 1.0 for $L=1$, 5,10 and $15 \mathrm{~kg} / \mathrm{m}^{2} \mathrm{~s}$, respectively. Hence, the Eulerian model with a TBR mesh comprising $10^{6}$ of tetrahedral cells for both hydrodynamic parameters was likely to perform better at the highest liquid flow rates since at $L=15 \mathrm{~kg} / \mathrm{m}^{2} \mathrm{~s}$ it were found the lower relative error percentages between its predictions and experimental data [42].

The optimization of time step with respect to liquid holdup predictions is shown in Fig. 4 at $G=0.1 \mathrm{~kg} / \mathrm{m}^{2} \mathrm{~s}$ and $P=30$ bar. As expected, a time step too large led to the worst concordance between the numerical predictions and experimental results. The relative error obtained with time step of $10^{-2}$ s was $34.3,26.1,21.8$ and 17.4 for $L=1,5,10$ and $15 \mathrm{~kg} / \mathrm{m}^{2} \mathrm{~s}$, respectively. A significant decrease down to $10^{-5} \mathrm{~s}$ led to the better agreement with $10^{6}$ of tetrahedral cells. In this case, the relative error became 1.5, 1.3, 1.2 and $1.0 \%$ when increasing the liquid flow rate from 1 to $15 \mathrm{~kg} / \mathrm{m}^{2} \mathrm{~s}$. In terms of frictional pressure drop as depicted in Fig. 5, the CFD predictions gave a relative error of $37.1,29.3,23.4,20.0 \%$ and 1.6 , $1.3,1.1$ and $1.0 \%$ for time steps of $10^{-2}$ and $10^{-5} \mathrm{~s}$, respectively. It is worth noting that a further decrease in the time step may be responsible for some degree of numerical instability or likely disturbed behaviour without giving relevant and feasible calculations for either liquid holdup or pressure drop. Therefore, after the comparison between the influence of time step on the liquid holdup and pressure drop calculations, a value of $10^{-5} \mathrm{~s}$ gave time step independent results when using a finer mesh $\left(10^{6}\right.$ of tetrahedral cells).

\subsection{Influence of distributor geometry}

In most CFD simulations of trickle-beds reported in the open literature, the fluid distribution at the inlet was treated as perfectly uniform in the radial direction so that all fluid enters at a given superficial velocity either in the wall or at the column centre. However, real distributors have discrete orifices where liquid and gas enter the trickle-bed reactor, interspersed with closed areas where no fluid enters. Three liquid distributors are employed in the computational runs. First, a single-point entry is simulated (distributor D1) and it is located at the column axis in the top of the bed with $0.2 \mathrm{~mm}$ diameter. Second, a distributor was designed with 60 capillary tubes $(0.12 \mathrm{~mm}$ internal diameter: distributor D2) which is used to replicate the distributor in our pilot plant. A similar configuration with 42 capillary tubes previously used by Pintar et al. who found this configuration to be appropriate for maintaining the flux of both phases approximately uniform over the cross-sectional area [43]. Finally, a perfectly uniform distributor (D3) was used to simulate the ideal case in where the fluids were allowed to enter the column at constant velocity using the total available entrance area.

In Fig. 6, the time and axially averaged CFD liquid holdup predictions were plotted at different relative axial positions $\left(z^{*}=z / L\right)$ for the single-point, 60 -hole and uniform distributor at $G=0.3 \mathrm{~kg} / \mathrm{m}^{2} \mathrm{~s}$ and $P=30$ bar. The CFD simulations performed with the lowest liquid flow rate $\left(L=2 \mathrm{~kg} / \mathrm{m}^{2} \mathrm{~s}\right)$ showed the prominent effect of the distributor geometry in multiphase flow distribution as depicted at $z^{*}=1 / 4$ with $\mathrm{D} 1$ distributor. It can be seen that the liquid phase tended to agglomerate predominantly at one side of the wall and then decreased significantly to the opposite side. With respect the mean value of liquid holdup the maxima and minima values were (4.1, -2.6), (2.6, -4.5), (3.7, -3.0), $(5.5,-8.4) \%$ for $z^{*}=1 / 4,1 / 2,3 / 4$ and 1 with the single-point distributor (D1), respectively. The absolute values (maxima, minima) for the liquid holdup predictions at $L=2 \mathrm{~kg} / \mathrm{m}^{2} \mathrm{~s}$ with $\{\mathrm{D} 1, \mathrm{D} 2, \mathrm{D} 3\}$ distributors were $\{(0.126,0.118)$, $(0.126,0.123),(0.127,0.123)\}$ at $z^{*}=1 / 4$. At $z^{*}=1 / 2:\{(0.128,0.119)$, $(0.128,0.123),(0.127,0.124)\}$; at $z^{*}=3 / 4:\{(0.129,0.121),(0.127$, $0.120),(0.126,0.122)\}$; and at $z^{*}=1:\{(0.128,0.111),(0.129,0.117)$, $(0.128,0.119)\}$. As one can conclude, the liquid flow distribution degrades as one moves along the packed bed being this fact supported by the increasing difference between maxima and minima liquid holdup values. The oscillatory behaviour may be attributed to the local effects near the catalyst particle surface which produces likely the wall effect phenomena or channelling as observed experimentally using high-resolution gamma ray tomography [44]. Gamma ray computed tomography is known to be better suited when high radiation energy is needed in comparison with magnetic resonance imaging, e.g. in the case of large reactor diameters, dense packing and in the case of steel walls and steel facilities for pressurized operation. Schubert et al. (2008) identified the above fact and claimed that the dynamic liquid saturation distribution indicates the development of liquid channels and regions which are completely separated from the flowing liquid with a glass packing. Moreover, the number and the dimension of the liquid channels increase with increasing liquid flow rate [44]. The influence of distributor geometry on the maldistribution of the dynamic liquid holdup was analyzed for a spray nozzle producing a uniform initial distribution and a point source distributor producing a central liquid stream in both glass bead bed and porous catalyst bed. The experimental observations were similar to those advanced theoretically with the Eulerian predictions shown in Fig. 6.

Fig. 7 shows an instantaneous snapshot of liquid holdup taken at the two axial planes depicted in Fig. 1. According to Fig. 7 it was possible to identify qualitatively the $3 \mathrm{D}$ distribution of liquid phase in the packed bed. At $L=2 \mathrm{~kg} / \mathrm{m}^{2} \mathrm{~s}$ and $P=30$ bar, one can observe that the higher liquid holdup values were monitored on the catalyst surface, as expected. Indeed, it was also confirmed the difference between the maxima and minima values attained at the lowest liquid flow rate in the range $0.18-0.22$. Concerning the 60 -hole distributor (D2), these values were $(1.0,-1.6),(2.6,-4.5),(3.7,-3.0)$, $(5.5,-8.2) \%$ while with D3 distributor were $(1.1,-1.1),(1.7,-2.2)$, $(2.5,-3.2),(4.5,-5.8) \%$ for $z^{*}=1 / 4,1 / 2,3 / 4$ and 1 , respectively. From these time averaged values, it can be pointed out that a ideal dis- 

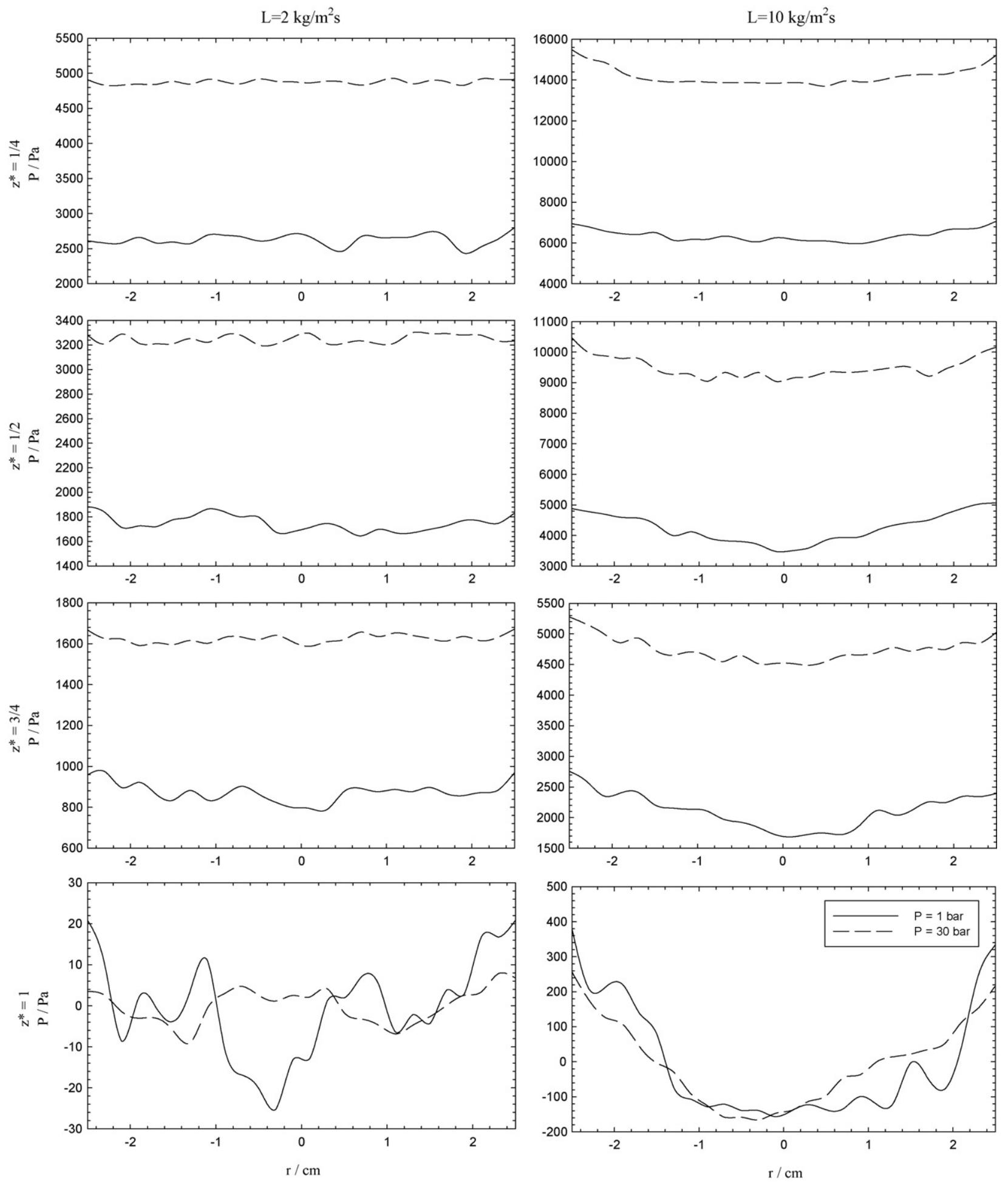

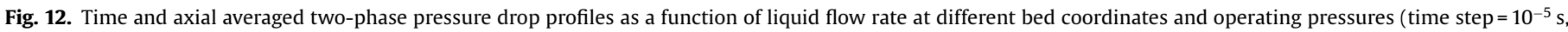
$10^{6}$ of tetrahedral cells, $G=0.3 \mathrm{~kg} / \mathrm{m}^{2} \mathrm{~s}, d_{\mathrm{p}}=2 \mathrm{~mm}$, D2 distributor).

tributor (D3) did not differ too much from the 60-hole distributor (D2) whereas the CFD simulations performed with the single-point distributor (D1) showed strongly radial profiles in terms of liquid holdup.

Increasing the liquid flow rate up to $L=10 \mathrm{~kg} / \mathrm{m}^{2} \mathrm{~s}$, Fig. 6 also displays the radial profiles of liquid holdup obtained with different distributors at $G=0.3 \mathrm{~kg} / \mathrm{m}^{2} \mathrm{~s}$ and $P=30$ bar. According to this time and axial averaged liquid holdup values, it is clear a preferential and persistent behaviour of liquid flow through the trickle-bed reactor. The higher values were observed at the reactor centre which demonstrates likely the Poiseuille flow. It seems that an increase of liquid flow rate up to $10 \mathrm{~kg} / \mathrm{m}^{2}$ s plays a dominant role over the distributor geometry even for D1 distributor. Moreover, this behaviour remains at different axial positions. It should be also stressed that we are on the boundary of trickling flow regime so that a further increase on either gas or liquid flow rates may shift the hydro- 


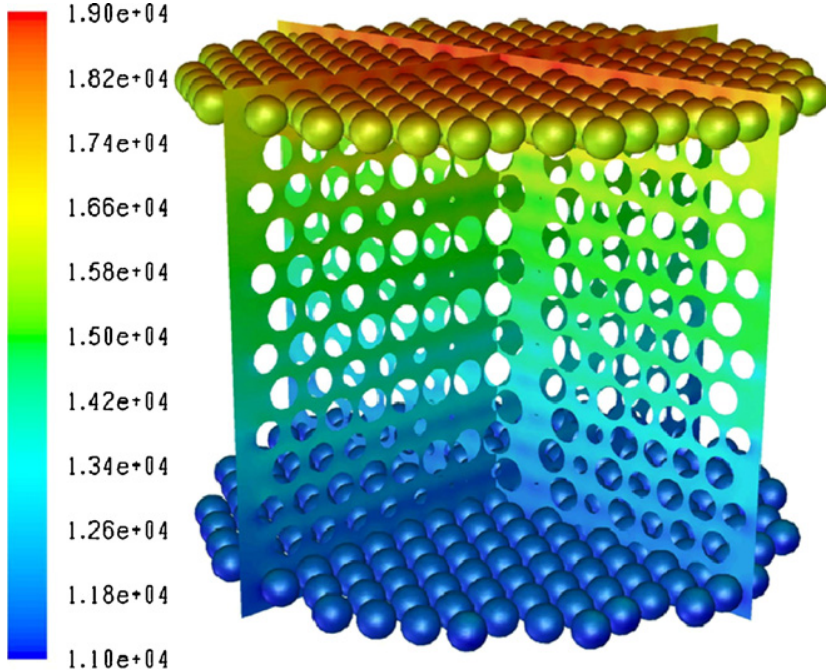

Fig. 13. Instantaneous snapshot of pressure field taken at two axial planes (Fig. 1) and two catalyst layers (time step $=10^{-5} \mathrm{~s}, 10^{6}$ of tetrahedral cells, $L=10 \mathrm{~kg} / \mathrm{m}^{2} \mathrm{~s}$, $G=0.3 \mathrm{~kg} / \mathrm{m}^{2} \mathrm{~s}, P=30$ bar, $d_{\mathrm{p}}=2 \mathrm{~mm}$, D2 distributor).

dynamic regime towards the pulsing flow. As we are concerned about the effect of gas-liquid flow rates on the trickling flow, the remaining of the discussion is only applicable in those operating conditions. The maxima and minima values for the radial liquid holdup values were $(6.5,-7.0),(7.6,-12.3),(10.5,-14.1),(13.9$, $-14.0)$ for $z^{*}=1 / 4,1 / 2,3 / 4$ and 1 with the single-point distributor (D1). These values were very similar to those obtained with the ideal distributor (D3): $(7.0,-8.9),(5.2,-13.2),(13.1,-14.8)$, $(14.2,-13.2)$. Therefore, it seems that the distributor geometry plays a major effect on hydrodynamics at lower interaction regimes ( $L=2 \mathrm{~kg} / \mathrm{m}^{2} \mathrm{~s}$ ) while the liquid flow rate control the multiphase flow radial distribution at higher interaction regimes $\left(L=10 \mathrm{~kg} / \mathrm{m}^{2} \mathrm{~s}\right)$. The absolute values (maxima, minima) for the liquid holdup predictions at $L=10 \mathrm{~kg} / \mathrm{m}^{2} \mathrm{~s}$ with $\{\mathrm{D} 1, \mathrm{D} 2, \mathrm{D} 3\}$ distributors were $\{(0.215$, $0.188),(0.218,0.183),(0.216,0.184)\}$ at $z^{*}=1 / 4$. At $z^{*}=1 / 2:\{(0.220$, $0.179),(0.222,0.182),(0.220,0.177)\}$; at $z^{*}=3 / 4:\{(0.230,0.179)$, (0.231, 0.180), $(0.229,0.172)\}$; and at $z^{*}=1:\{(0.241,0.182),(0.243$, $0.180),(0.237,0.180)\}$.

At $L=2 \mathrm{~kg} / \mathrm{m}^{2} \mathrm{~s}$, the time and radial averaged liquid holdup predictions were plotted in Fig. 8 while the CFD calculations performed at $L=10 \mathrm{~kg} / \mathrm{m}^{2} \mathrm{~s}$ is shown in Fig. 9 both at $G=0.3 \mathrm{~kg} / \mathrm{m}^{2} \mathrm{~s}$ and $P=30$ bar. As it can be seen, there is no significant qualitative difference between these two axial liquid holdup profiles with different distributors at different liquid flow rates. The main difference detected was in the magnitude of maxima and minima values attained with the quantitative comparison of liquid holdup. In fact, the maxima and minima values obtained at $L=2 \mathrm{~kg} / \mathrm{m}^{2} \mathrm{~s}$ were $\pm 15 \%$ while at $L=10 \mathrm{~kg} / \mathrm{m}^{2} \mathrm{~s}$ were $\pm 7 \%$. Once more, the distributor geometry seems to have no effect on the axial liquid flow distribution but only the liquid flow rate can affect considerably the intensity of liquid holdup spots at $P=30$ bar.

\subsection{Effect of liquid flow rate}

At a constant gas flow rate $\left(G=0.3 \mathrm{~kg} / \mathrm{m}^{2} \mathrm{~s}\right)$, Fig. 10 shows the time averaged radial profiles for the liquid holdup predictions at different axial positions and at different liquid flow rates with the 60 -hole distributor. At the lowest liquid flow rate $\left(L=2 \mathrm{~kg} / \mathrm{m}^{2} \mathrm{~s}\right)$, it can be seen that the radial liquid distribution began with approximately a flat profile and suffered some degree of perturbation as one moves along the packed bed. One should also compare the level of the higher and lower liquid holdup traces. For a uniform distribu- tion, the liquid holdup from the left-hand side and the right-hand side of radial coordinate should be at the same level. However, the maxima and minima liquid holdup values attained with the lowest liquid flow rate were $(1.0,-1.6),(1.7,-2.9),(2.5,-5.0),(5.7$, $-6.4) \%$ for $z^{*}=1 / 4,1 / 2,3 / 4$ and 1 at $P=30$ bar. These values were even higher with the highest liquid flow rate: $(7.5,-9.4),(10.1$, $-10.0),(14.3,-10.8),(17.1,-13.3) \%$ for the equivalent axial positions. The absolute values (maxima, minima) for the liquid holdup predictions at $L=2 \mathrm{~kg} / \mathrm{m}^{2} \mathrm{~s}$ and $P=\{1,30\}$ bar were $\{(0.184,0.176)$, $(0.126,0.123)\}$ at $z^{*}=1 / 4$. At $z^{*}=1 / 2:\{(0.190,0.175),(0.128,0.122)\}$; at $z^{*}=3 / 4:\{(0.191,0.172),(0.127,0.118)\}$; and at $z^{*}=1:\{(0.197,0.167)$, $(0.131,0.116)\}$. Again, it was confirmed that the higher liquid holdup values were found in the column centre. Therefore, the liquid flow rate have a propensity effect on the hydrodynamics at higher values but it can also be stated that is not sufficient to improve the liquid distribution by itself. Regarding the time and radial averaged profiles, Fig. 11 displays the axial liquid holdup profiles with different liquid flow rates with D2 distributor at $G=0.3 \mathrm{~kg} / \mathrm{m}^{2} \mathrm{~s}$ and $P=30$ bar. As already advanced for the explanation of the influence of liquid distributor, the axial liquid distribution did not show a tendentious behaviour across the packed bed. Indeed, the only distinction detected was related to the smooth liquid holdup profile exhibited at the highest liquid flow rate [17]. The absolute values (maxima, minima) for the liquid holdup predictions at $L=2 \mathrm{~kg} / \mathrm{m}^{2} \mathrm{~s}$ and $P=\{1,30\}$ bar were $\{(0.282,0.234),(0.218,0.183)\}$ at $z^{*}=1 / 4$. At $z^{*}=1 / 2:\{(0.289,0.224),(0.222,0.182)\} ;$ at $z^{*}=3 / 4:\{(0.300,0.223)$, $(0.231,0.180)\}$; and at $z^{*}=1:\{(0.327,0.225),(0.243,0.180)\}$. The increase of liquid flow rate decreased the maxima/minima liquid holdup values from $(14.7,-11.2) \%$ with $L=2 \mathrm{~kg} / \mathrm{m}^{2} \mathrm{~s}$ to $(5.2,-4.7) \%$ with $L=10 \mathrm{~kg} / \mathrm{m}^{2}$ s.

Time and axial averaged profiles for two-phase pressure drop predictions is shown in Fig. 12 at $G=0.3 \mathrm{~kg} / \mathrm{m}^{2} \mathrm{~s}$ and $P=30$ bar. According to these radial profiles, it was found that pressure drop was higher at the TBR centre mainly with the highest simulated liquid flow rate $\left(L=10 \mathrm{~kg} / \mathrm{m}^{2} \mathrm{~s}\right)$. While the frictional pressure drop maxima/minima were about $2-3 \%$ at $L=2 \mathrm{~kg} / \mathrm{m}^{2} \mathrm{~s}$, these values were shifted up to $11 \%$ at $L=10 \mathrm{~kg} / \mathrm{m}^{2} \mathrm{~s}$. In fact, the computed results were $(9.0,-3.6),(10.3,-4.8),(11.1,-5.5) \%$ for $z^{*}=1 / 4,1 / 2,3 / 4$, respectively. Therefore, the effect of liquid flow rate on radial pressure drop profiles was more pronounced if the reactor is operated under higher interaction liquid flow regimes. In what concerns the axial pressure field, Fig. 13 shows a contour map of relative pressure values in two axial planes. As one can observe, with 13 catalyst layers the pressure decrease from 19,000 to $11,000 \mathrm{~Pa}$ at $L=10 \mathrm{~kg} / \mathrm{m}^{2} \mathrm{~s}$, $G=0.3 \mathrm{~kg} / \mathrm{m}^{2} \mathrm{~s}$ and $P=30 \mathrm{bar}$, as validated accordingly in Fig. 3 .

\subsection{Effect of gas flow rate}

In Fig. 14 it was plotted the time and axial averaged liquid holdup predictions at a constant liquid flow rate $\left(L=5 \mathrm{~kg} / \mathrm{m}^{2} \mathrm{~s}\right)$ with D2 distributor at different axial positions. At the lowest gas flow rate $\left(G=0.1 \mathrm{~kg} / \mathrm{m}^{2} \mathrm{~s}\right)$ and $=30 \mathrm{bar}$, the maxima/minima liquid holdup values were $(3.3,-3.4),(5.0,-3.4),(8.5,-9.5),(12.2,-11.1) \%$ for $z^{*}=1 / 4,1 / 2,3 / 4$ and 1 , respectively. The absolute values (maxima, minima) for the liquid holdup predictions at $G=0.1 \mathrm{~kg} / \mathrm{m}^{2} \mathrm{~s}$ and $P=\{1,30\}$ bar were $\{(0.248,0.228),(0.171,0.160)\}$ at $z^{*}=1 / 4$. At $z^{*}=1 / 2:\{(0.255,0.228),(0.174,0.160)\} ;$ at $z^{*}=3 / 4:\{(0.262,0.215)$, $(0.180,0.150)\}$; and at $z^{*}=1:\{(0.272,0.206),(0.186,0.147)\}$. As one can conclude, these values are increasing along the packed which degrade considerably the liquid distribution. Moreover, the computed profile attained for $z^{*}=3 / 4$ and 1 illustrated a remarkable degree of inhomogeneity of radial liquid distribution. Increasing the gas flow rate up to $0.7 \mathrm{~kg} / \mathrm{m}^{2} \mathrm{~s}$, the CFD simulations of radial liquid holdup profiles are shown equally in Fig. 14. The increase of gas flow rate was found to be responsible for the enlargement of maxima/minima liquid holdup values with respect to the mean 

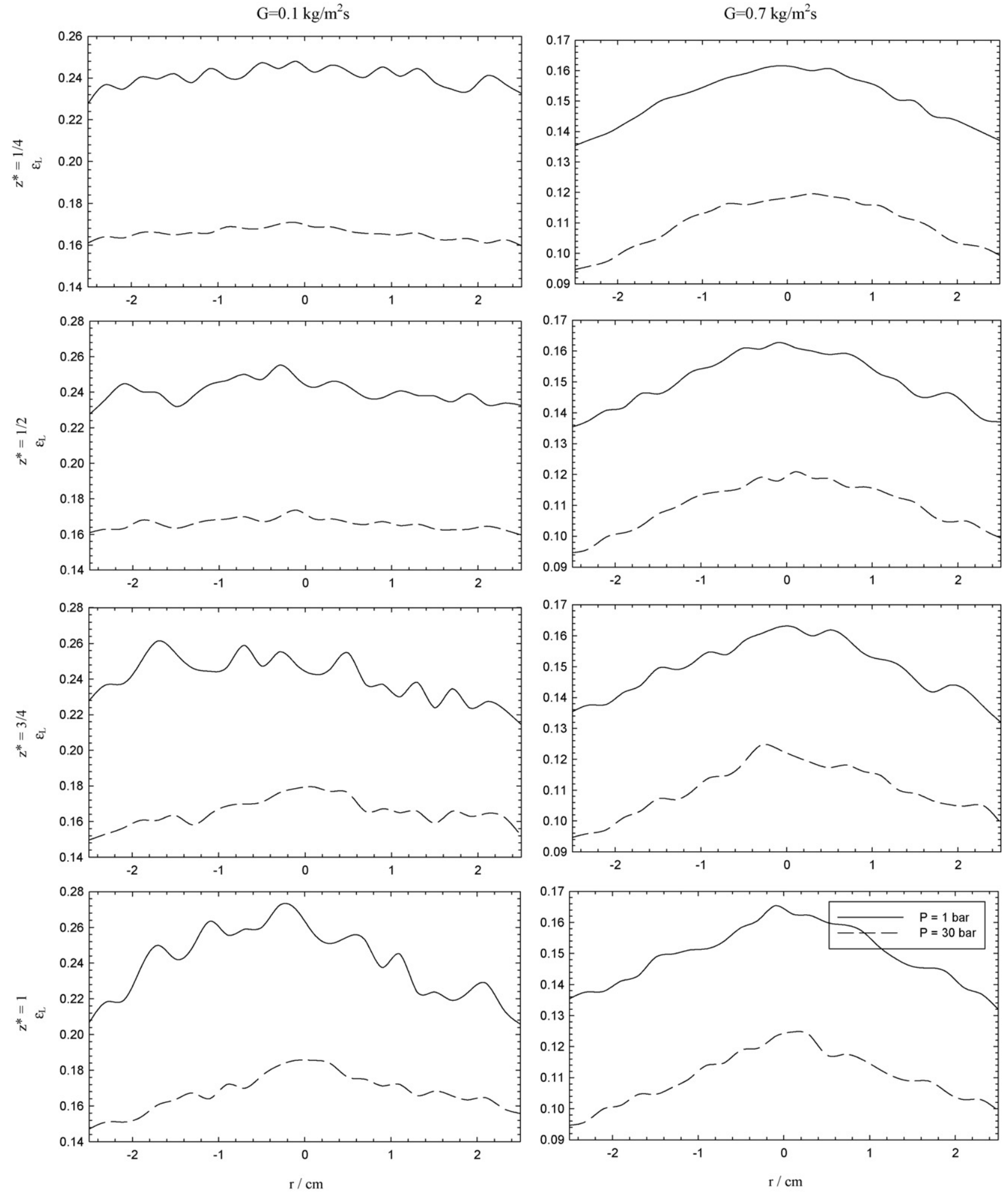

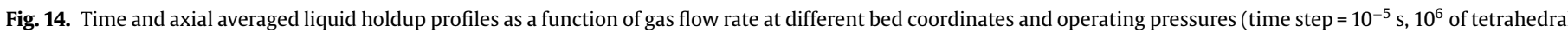
cells, $L=5 \mathrm{~kg} / \mathrm{m}^{2} \mathrm{~s}, d_{\mathrm{p}}=2 \mathrm{~mm}$, D2 distributor)

value. In fact, at $G=0.7 \mathrm{~kg} / \mathrm{m}^{2}$ s and $P=30$ bar, these values were $(9.2$, $-13.5),(10.4,-13.6),(13.7,-13.6),(13.8,-13.7)$ for $z^{*}=1 / 4,1 / 2,3 / 4$ and 1 , respectively. The absolute values (maxima, minima) for the liquid holdup predictions at $G=0.7 \mathrm{~kg} / \mathrm{m}^{2} \mathrm{~s}$ and $P=\{1,30\}$ bar were $\{(0.162,0.135),(0.120,0.095)\}$ at $z^{*}=1 / 4$. At $z^{*}=1 / 2:\{(0.163,0.135)$, $(0.121,0.095)\}$; at $z^{*}=3 / 4:\{(0.162,0.132),(0.125,0.096)\}$; and at $z^{*}=1:\{(0.165,0.132),(0.125,0.096)\}$.
Time and radial averaged liquid holdup profiles are shown in Fig. 15 at $L=15 \mathrm{~kg} / \mathrm{m}^{2} \mathrm{~s}$ and $P=30$ bar with $\mathrm{D} 2$ distributor. As one can observe, the increase of gas flow rate was also found to smooth the axial liquid distribution as the liquid flow rate did. However, the increase of five times of liquid flow rate from $L=2$ to $10 \mathrm{~kg} / \mathrm{m}^{2} \mathrm{~s}$ did not have the extensive and sizeable effect as the increase of seven times on the gas flow rate from $G=0.1$ to $0.7 \mathrm{~kg} / \mathrm{m}^{2} \mathrm{~s}$. As the liq- 


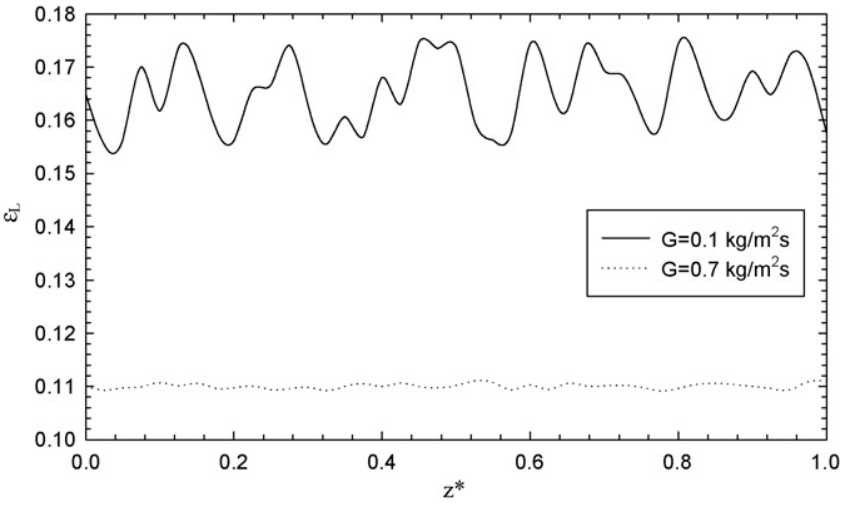

Fig. 15. Time and radial averaged liquid holdup profiles at different gas flow rates (time step $=10^{-5} \mathrm{~s}, 10^{6}$ of tetrahedral cells, $L=5 \mathrm{~kg} / \mathrm{m}^{2} \mathrm{~s}, P=30 \mathrm{bar}, d_{\mathrm{p}}=2 \mathrm{~mm}$, D2 distributor).

uid and gas phase tend to flow an uneven route across the packed bed, the intensification of gas flow into the liquid-solid system smoothens the liquid distribution. An increase in gas flow rate is well-known to decrease the wall flow so that an increase in liquid flow and/or gas throughputs leading also to the increase of two-phase pressure drop may improve substantially to better liquid distribution. In fact, the maxima/minima values for the axial liquid holdup values were $(5.7,-5.9)$ and $(0.9,-0.8) \%$ for $G=0.1$ and $0.7 \mathrm{~kg} / \mathrm{m}^{2} \mathrm{~s}$, respectively. Notwithstanding a better radial liquid distribution can be achieved with higher gas flow rates, the instantaneous snapshot of velocity field for the gas phase is still exhibiting a heterogeneous behaviour. This local effects is the result of interstitial phenomena as depicted in the velocity vector plot in Fig. 16 at $G=0.7 \mathrm{~kg} / \mathrm{m}^{2}$ s and $P=30$ bar. Concomitantly, Fig. 17 also supported this fact with the illustration of gas streamlines coloured by the respective Reynolds number at the same operating conditions. As it can be seen, the velocity spots are observed predominantly near the catalyst particles and at the wall. The map of Reynolds number shown in Fig. 17 demonstrated that one can feature values up to 2500 so that the $k-\varepsilon$ dispersed turbulence model can be regarded as a rational choice to capture the turbulence at the higher interaction regimes.

Time and axial averaged frictional pressure drop profiles attained with different gas flow rates are shown in Fig. 18 at $L=5 \mathrm{~kg} / \mathrm{m}^{2} \mathrm{~s}$ and $P=30$ bar. As it can be seen, the gas flow rate was found to have a greater impact on the liquid distribution with the lowest gas flow rate $\left(G=0.1 \mathrm{~kg} / \mathrm{m}^{2} \mathrm{~s}\right)$. The maxima/minima values computed for the two-phase pressure drop at the lowest gas flow rate were $(8.1,-6.5),(10.5,-8.2),(13.8,-7.3)$ for $z^{*}=1 / 4$, $1 / 2$ and $3 / 4$, respectively. For the highest simulated gas flow rate $\left(G=0.7 \mathrm{~kg} / \mathrm{m}^{2} \mathrm{~s}\right)$, these values were significantly lower: $(1.2,-0.8)$, $(1.6,-1.2),(2.0,-1.1) \%$ as one moves across the packed bed. Therefore, whereas the liquid flow rate seems to have a predominant effect on radial pressure drop profiles at the higher values, the gas flow rates have it major outcome at lower regimes.

\subsection{Effect of operating pressure}

As the packed bed flow not only depends on liquid and gas superficial velocities as well as on the physico-chemical properties and on the ratio of column diameter to particle diameter, one should also pay attention whether the TBR is pressurized or not. Hence, Figs. 10 and 12 plot also the effect of operating pressure on both radial liquid holdup and two-pressure drop profiles at $G=0.3 \mathrm{~kg} / \mathrm{m}^{2} \mathrm{~s}$ for two different liquid flow rates and operating pressures. When the operation is simulated at atmospheric conditions ( $P=1 \mathrm{bar}$ ), the liquid holdup values were found to be

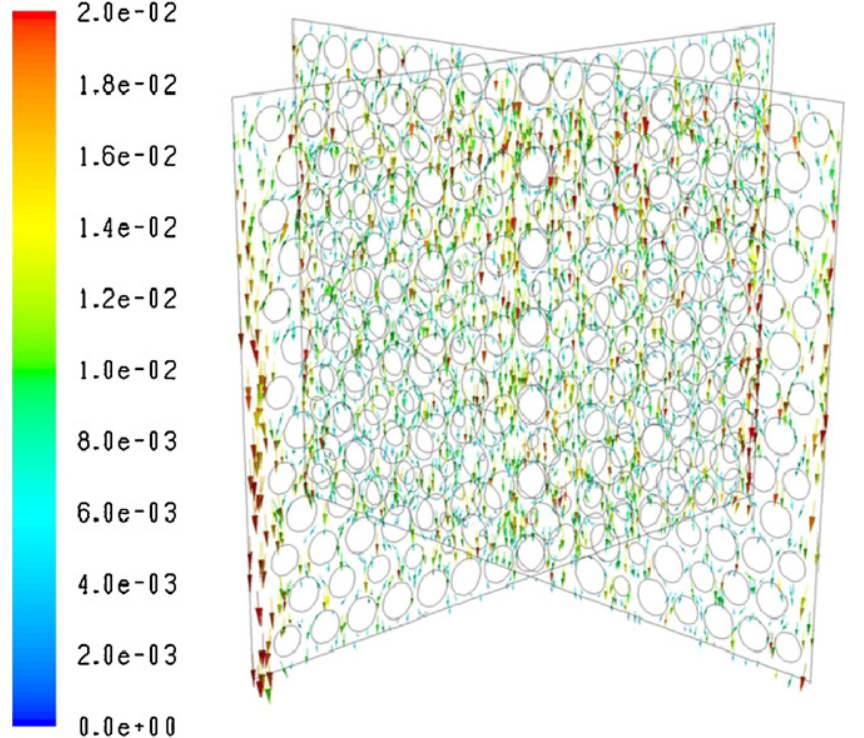

Fig. 16. Gas velocity vector plot taken at two axial planes shown in Fig. 1 (time step $=10^{-5} \mathrm{~s}, 10^{6}$ of tetrahedral cells, $L=5 \mathrm{~kg} / \mathrm{m}^{2} \mathrm{~s}, G=0.7 \mathrm{~kg} / \mathrm{m}^{2} \mathrm{~s}, P=30$ bar, $d_{\mathrm{p}}=2 \mathrm{~mm}$, D2 distributor).

substantially higher than those obtained with a pressurized tricklebed reactor $(P=30$ bar $)$. At the lowest liquid flow rate $\left(L=2 \mathrm{~kg} / \mathrm{m}^{2} \mathrm{~s}\right)$, the maxima/minima values for liquid holdup predictions increased from $(1.0,-1.6),(1.7,-2.9),(2.5,-5.0),(5.7,-6.4) \%$ at $P=30$ bar to $(1.9,-2.3),(4.2,-4.2),(4.8,-5.7),(7.9,-8.4) \%$ at $P=1$ bar for $z^{*}=1 / 4$, $1 / 2,3 / 4$ and 1 , respectively. At $L=10 \mathrm{~kg} / \mathrm{m}^{2} \mathrm{~s}$, the shift was from (7.5, -9.4), (10.1, -10.0), (14.3,-10.8), (17.1, -13.3$) \%$ at $P=30$ bar to (8.3, -9.9), (12.6, -12.7), (15.5, -14.2), $(25.5,-13.5) \%$ at $P=1$ bar. Generally, the higher operating pressure the smoother radial liquid holdup profile. Moreover, at a constant gas and liquid flow rate the increase of operating pressure seems to give a better performance with respect to the radial liquid distribution. For this reason, the irregularities verified at lower interaction regimes can be further eliminated or at least dissipated with the respective increase of operating pressure.

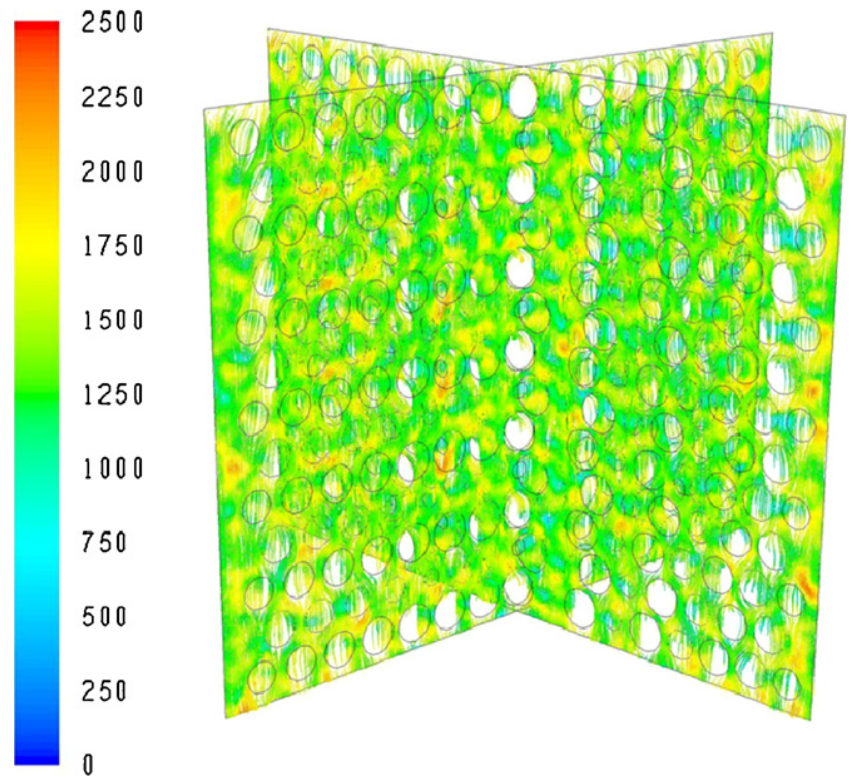

Fig. 17. Instantaneous gas streamlines coloured by Reynolds number taken at two axial planes shown in Fig. 1 (time step $=10^{-5} \mathrm{~s}, 10^{6}$ of tetrahedral cells, $L=5 \mathrm{~kg} / \mathrm{m}^{2} \mathrm{~s}$, $G=0.7 \mathrm{~kg} / \mathrm{m}^{2} \mathrm{~s}, P=30$ bar, $d_{\mathrm{p}}=2 \mathrm{~mm}$, D2 distributor). 

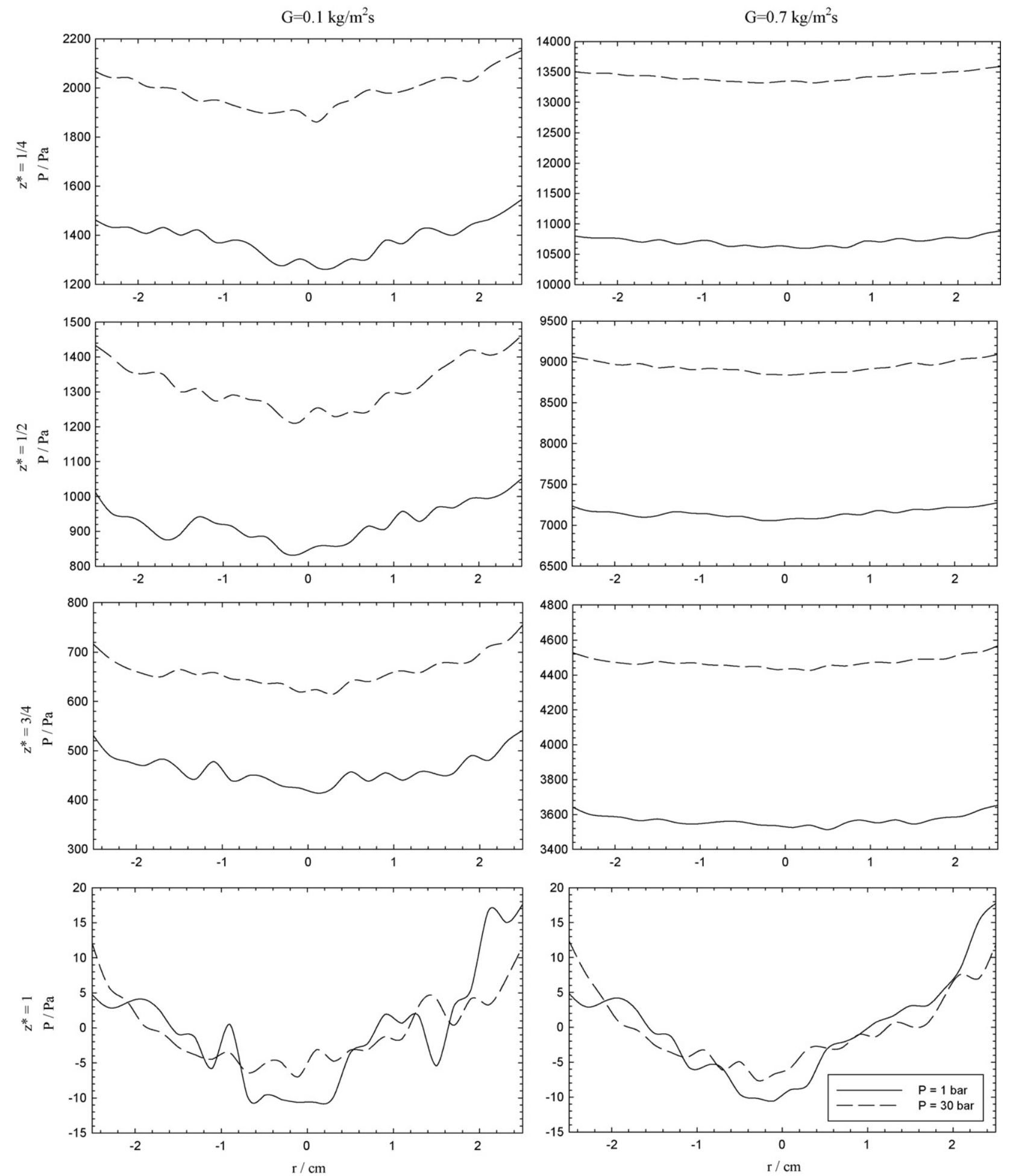

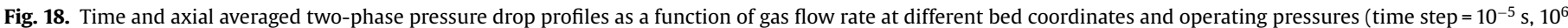
of tetrahedral cells, $L=5 \mathrm{~kg} / \mathrm{m}^{2} \mathrm{~s}, d_{\mathrm{p}}=2 \mathrm{~mm}$, D2 distributor).

Time and axial averaged liquid holdup and two-phase pressure drop profiles plotted in Figs. 14 and 18 also demonstrated the effect of operating pressure for both hydrodynamic parameters. At the lowest gas flow rate $\left(G=0.1 \mathrm{~kg} / \mathrm{m}^{2} \mathrm{~s}\right)$, the maxima/minima liquid holdup values shifted from $(3.3,-3.4),(5.0,-3.4),(8.5,-9.5),(12.2$, $-11.1) \%$ at $P=30$ bar to $(3.3,-5.2),(6.3,-5.2),(8.9,-10.7),(13.3$, $-14.3) \%$ for $z^{*}=1 / 4,1 / 2,3 / 4$ and 1 , respectively. Therefore, the radial liquid distribution is smoothened as long as the operating pressure is increased. This fact can be also supported at either higher gas flow rates $\left(G=0.7 \mathrm{~kg} / \mathrm{m}^{2} \mathrm{~s}\right)$ or even in terms of radial two-phase pressure drop profiles computed across the trickle-bed reactor.

\section{Conclusions}

The improper liquid distribution has been found as one of the major reasons for non-optimal use of the catalyst, rapid deactivation and thermal instability in trickle-bed reactors. Despite the work carried out so far, many questions still remain unresolved, 
particularly concerning the evaluation of local phenomena at the catalyst scale that may be responsible for the integral behaviour of an entire industrial TBR unit. Bearing in mind that the reliable design of TBR is still concerned with trustworthy experimental data on the factors promoting uniform liquid distribution, a TBR was modelled by means of a Eulerian multiphase model at highpressure.

First, the CFD model was validated under trickling flow regime and its predictions were compared against the experimental liquid holdup and two-phase pressure drop data. The model was optimized in terms of mesh size and time step giving reasonable predictions for both hydrodynamic parameters. Afterwards, the influence of liquid distributor at the top of the bed was evaluated through the comparison between a single-point entry, 60-hole and a perfectly uniform distributor. The 60-hole distributor was found to be a good compromise if one is concerned on reactor performance since it allowed a better liquid distribution.

Second, several computational runs were performed to investigate time averaged axial and radial profiles of liquid holdup and two-phase pressure drop. The liquid flow rate had more prominent effect on radial pressure drop at higher values. Alternatively, the gas flow rate had a pronounced influence at lower interaction regimes. The increase of operating pressure on multiphase flow distribution was found to smooth the radial profiles for both hydrodynamic parameters.

\section{Acknowledgments}

The authors gratefully acknowledged the financial support of REMOVALS - 6th Framework Program for Research and Technological Development - FP06 Project no. 018525 and Fundação para a Ciência e Tecnologia, Portugal.

\section{References}

[1] C.N. Satterfield, Trickle-bed reactors, A.I.Ch.E. Journal 21 (1975) 209-228.

[2] A. Gianetto, B.V. Specchia, S. Sicardi, Hydrodynamics and solid-liquid contacting effectiveness in trickle-bed reactors, A.I.Ch.E. Journal 24 (1978) 1087-1104.

[3] M. Herskowitz, J.M. Smith, Trickle-bed reactors: a review, A.I.Ch.E. Journal 29 (1983) 1-18.

[4] M.H. Al-Dahhan, F. Larachi, M.P. Dudukovic, A. Laurent, High pressure tricklebed reactors: a review, Industrial and Engineering Chemistry Research 36 (8) (1997) 3292-3314.

[5] M.P. Dudukovic, F. Larachi, P.L. Mills, Multiphase catalytic reactors: a perspective on current knowledge and future trends, Catalysis Reviews: Science and Engineering 44 (1) (2002) 123-246.

[6] F. Larachi, B. Lamia, I. Ion, P.A.G. Bernard, Heat and mass transfer in co-current gas-liquid packed beds: analysis, recommendations and new correlations, Industrial \& Engineering Chemistry Research 42 (2003) 222-242.

[7] S.K. Bhargava, J. Tardio, J. Prasad, K. Foger, D.B. Akolekar, S.C. Grocott, Wet oxidation and catalytic wet oxidation, Industrial \& Engineering Chemistry Research 45 (4) (2006) 1221-1258.

[8] K.M. Ng, C.P. Chu, Trickle bed reactors, Chemical Engineering Progress 83 (1987) 55-63.

[9] N. Reinecke, D. Mewes, Tomographic imaging of trickle-bed reactors, Chemical Engineering Science 51 (1996) 2131-2138.

[10] A.J. Sederman, L.F. Gladden, Magnetic resonance imaging as a quantitative probe of gas-liquid distribution and wetting efficiency in trickle-bed reactors, Chemical Engineering Science 56 (2001) 2615-2628.

[11] I. Harter, C. Boyer, L. Raynal, G. Ferschneider, T. Gauthier, Flow distribution studies applied to deep hydro-desulfurization, Industrial \& Engineering Chemistry Research 40 (2001) 5262-5267.

[12] C. Boyer, B. Fanget, Measurement of liquid flow distribution in trickle bed reactor of large diameter with a new gamma-ray tomographic system, Chemical Engineering Science 57 (2002) 1079-1089.

[13] K. Onda, H. Takeuchi, Y. Maeda, N. Takeuchi, Liquid distribution in packed column, Chemical Engineering Science 28 (1973) 1677-1783.
[14] A.K. Saroha, K.D.P. Nigam, A.K. Saxena, V.K. Kapoor, Liquid distribution in tricklebed reactors, A.I.Ch.E. Journal 44 (1998) 2044-2052.

[15] M.H. Al-Dahhan, M.P. Dudukovic, Pressure drop and liquid holdup in high pressure trickle-bed reactors, Chemical Engineering Science 49 (1994) 5681-5698.

[16] J.G. Schwartz, E. Weger, M.P. Dudukovic, A new tracer method for the determination of liquid-solid contacting efficiency in trickle-bed reactors, A.I.Ch.E. Journal 22 (1976) 894-904.

[17] A. Kundu, A.K. Saroha, K.D.P. Nigam, Liquid distribution studies in trickle bed reactors, Chemical Engineering Science 56 (2001) 5963-5967.

[18] G.A. Funk, M.P. Harold, K.M. Ng, A novel model for reaction in trickle beds with flow maldistribution, Industrial and Engineering Chemistry Research 29 (1990) 738.

[19] M. Herskowitz, J.M. Smith, Liquid distribution in trickle-bed reactors, A.I.Ch.E. Journal 24 (1979) 439.

[20] M. Crine, P. Marchot, G.A. L'Homme, Mathematical modeling of the liquid trickling flow through a packed bed using the percolation theory, Computers and Chemical Engineering 3 (1979) 515.

[21] V.Stanek, J. Hanika, V. Hlavacek, O. Tranka, The effect of liquid flow distribution on the behavior of a trickle bed reactor, Chemical Engineering Science 36 (1981) 1045.

[22] S.P. Zimmerman, K.M. Ng, Liquid distribution in trickling flow trickle bed reactors, Chemical Engineering Science 41 (1986) 861

[23] R.O. Fox, One the liquid flow distribution in trickle-bed reactors, Industrial and Engineering Chemistry Research 26 (1987) 2413.

[24] T.R. Melli, L.E. Scriven, Theory of two-phase cocurrent downflow in networks of passages, Industrial and Engineering Chemistry Research 30 (1991) 951.

[25] A.E. Sáez, R.G. Carbonell, Hydrodynamic parameters for gas liquid cocurrent flow in packed beds, A.I.Ch.E. Journal 31 (1) (1985) 52-62.

[26] R.A. Holub, M.P. Dudukovic, P.A. Ramachandran, A phenomenological model for pressure-drop, liquid holdup, and flow regime transition in gas-liquid trickle flow, Chemical Engineering Science 47 (1992) 2343-2348.

[27] I. Iliuta, F. Larachi, M.H. Al-Dahhan, Double-slit model for partially wetted trickle flow hydrodynamics, A.I.Ch.E. Journal 46 (2000) 597-609.

[28] A. Attou, G.A. Ferschneider, Two-fluid model for flow regime transition in gas-liquid trickle-bed reactors, Chemical Engineering Science 54 (21) (1999) 5031-5037.

[29] A. Souadnia, M.A. Latifi, Analysis of two-phase flow distribution in trickle-bed reactors, Chemical Engineering Science 56 (2001) 5977-5985.

[30] A. Atta, S. Roy, K.D.P. Nigam, Prediction of pressure drop and liquid holdup in trickle bed reactor using relative permeability concept in CFD, Chemical Engineering Science 62 (21) (2007) 5870-5879.

[31] Y. Jiang, M.R. Khadilkar, M.H. Al-Dahhan, M.P. Dudukovic, CFD modeling of multiphase in packed bed reactors: results and applications, A.I.Ch.E. Journal 48 (2002) 716-730.

[32] P.R. Gunjal, M.N. Kashid, V.V. Ranade, R.V. Chaudhari, Hydrodynamics of tricklebed reactors: experiments and CFD modeling, Industrial and Engineering Chemistry Research 44 (2005) 6278-6294.

[33] FLUENT 6.1, User's Manual to FLUENT 6.1, Fluent Inc., Centrera Resource Park, 10 Cavendish Court, Lebanon, USA, 2005.

[34] A. Dybbs, R.V. Edwards, in: J. Bear, M. Corapcioglu (Eds.), Fundamentals of Transport Phenomena in Porous Media, Martins Nijhoff, Dordrecht, 1984.

[35] P.R. Gunjal, V.V. Ranade, R.V. Chaudhari, Computational study of a single-phase flow in packed beds of spheres, A.I.Ch.E. Journal 51 (2) (2005) 365-378.

[36] R.J.G. Lopes, R.M. Quinta-Ferreira, Trickle-bed CFD studies in the catalytic wet oxidation of phenolic acids, Chemical Engineering Science 62 (24) (2007) 7045-7052.

[37] S.A. Logtenberg, M. Nijemeisland, A.G. Dixon, Computational fluid dynamics simulations of fluid flow and heat transfer at the wall particle contact points in a fixed bed reactor, Chemical Engineering Science 54 (1999) 2433-2439.

[38] R.J.G. Lopes, R.M. Quinta-Ferreira, Three-dimensional numerical simulation of pressure drop and liquid holdup for high-pressure trickle-bed reactor, Chemical Engineering Journal 145 (1) (2008) 112-120.

[39] GAMBIT 2, User's Manual to GAMBIT 2, Fluent Inc., Centrera Resource Park, 10 Cavendish Court, Lebanon, USA, 2005

[40] S.A. Vasquez, V.A. Ivanov, A phase coupled method for solving multiphase problems on unstructured meshes, in: Proceedings of ASME FEDSM'00: ASME 2000 Fluids Engineering Division Summer Meeting, Boston, June 2000.

[41] S.V. Patankar, Numerical Heat Transfer and Fluid Flow, Hemisphere, Washington, DC, 1980.

[42] D. Nemec, J. Levec, Flow through packed bed reactors: 2. Two phase concurrent downflow, Chemical Engineering Science 60 (24) (2005) 6958-6970.

[43] A. Pintar, G. Berčič, J. Levec, Catalytic liquid-phase oxidation of aqueous phenol solutions in a trickle-bed reactor, Chemical Engineering Science 52 (1997) 4143-4153.

[44] M. Schubert, G. Hessel, C.Zippe, R. Lange, U. Hampel, Liquid flow texture analysis in trickle bed reactors using high-resolution gamma ray tomography, Chemical Engineering Journal 140 (2008) 332-340. 